Prepared in cooperation with the City of Lake Oswego, City of Wilsonville, Meyer Memorial Trust, and Benton Soil and Water Conservation District

\title{
Water Temperature in Tributaries, Off-Channel Features, and Main Channel of the Lower Willamette River, Northwestern Oregon, Summers 2016 and 2017
}

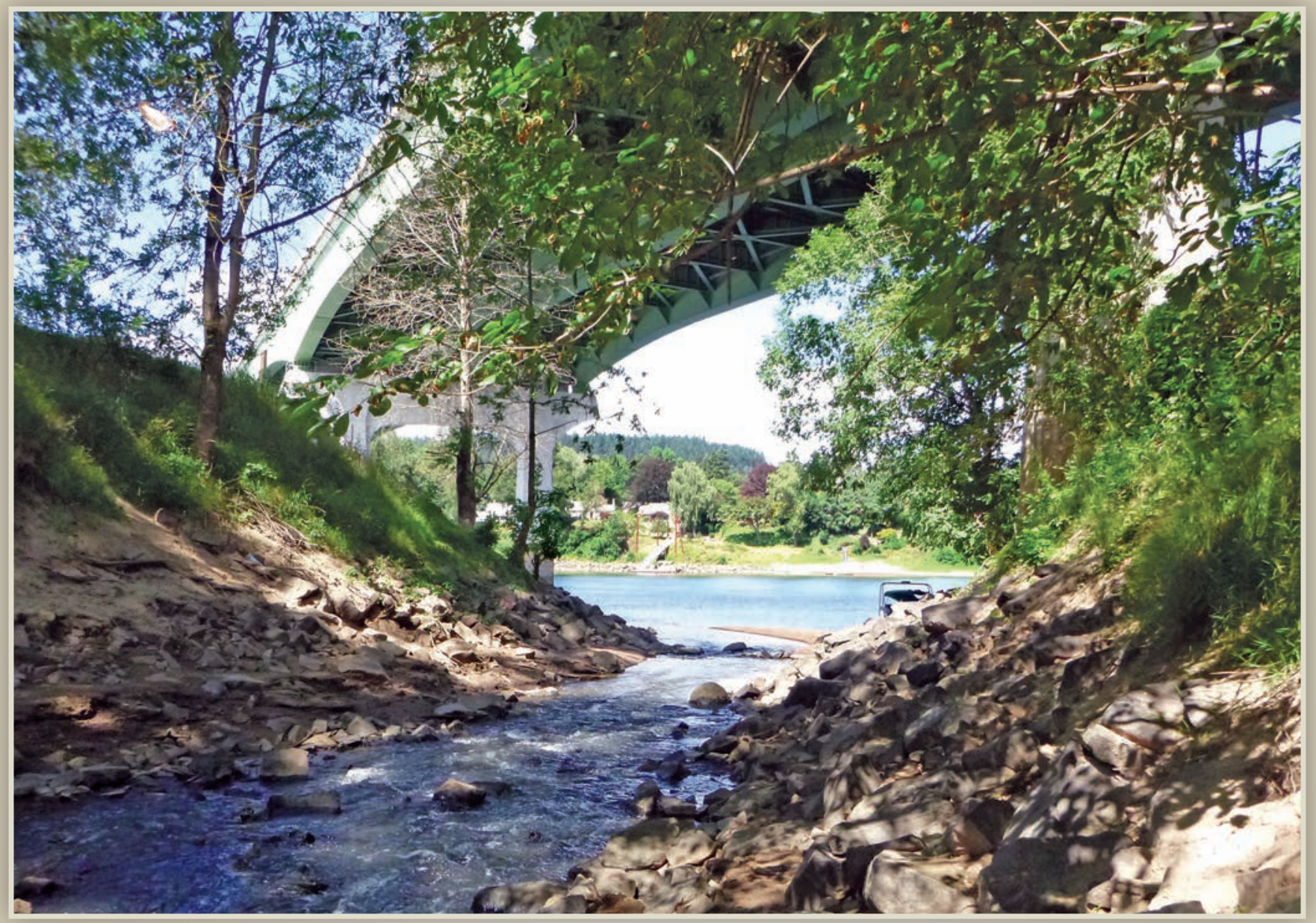

Open-File Report 2018-1184

U.S. Department of the Interior

U.S. Geological Survey 
Cover: Photograph of Abernathy Creek at its confluence with the Willamette River under the Interstate 205 bridge, at Oregon City, Oregon. Photograph by J.F. Mangano, U.S. Geological Survey, July 13, 2016. 


\section{Water Temperature in Tributaries, Off-Channel Features, and Main Channel of the Lower Willamette River, Northwestern Oregon, Summers 2016 and 2017}

By Joseph F. Mangano, David R. Piatt, Krista L. Jones, and Stewart A. Rounds

Prepared in cooperation with the City of Lake Oswego, City of Wilsonville, Meyer Memorial Trust, and Benton Soil and Water Conservation District

Open-File Report 2018-1184

U.S. Department of the Interior

U.S. Geological Survey 


\section{U.S. Department of the Interior \\ RYAN K. ZINKE, Secretary}

\section{U.S. Geological Survey \\ James F. Reilly II, Director}

U.S. Geological Survey, Reston, Virginia: 2018

For more information on the USGS-the Federal source for science about the Earth, its natural and living resources, natural hazards, and the environment-visit https://www.usgs.gov/ or call 1-888-ASK-USGS (1-888-275-8747).

For an overview of USGS information products, including maps, imagery, and publications, visit https:/store.usgs.gov.

Any use of trade, firm, or product names is for descriptive purposes only and does not imply endorsement by the U.S. Government.

Although this information product, for the most part, is in the public domain, it also may contain copyrighted materials as noted in the text. Permission to reproduce copyrighted items must be secured from the copyright owner.

Suggested citation:

Mangano, J.F., Piatt, D.R., Jones, K.L, and Rounds, S.A., 2018, Water temperature in tributaries, off-channel features, and main channel of the lower Willamette River, northwestern Oregon, summers 2016 and 2017: U.S. Geological Survey Open-File Report 2018-1184, 33 p., https://doi.org/10.3133/ofr20181184.

ISSN 2331-1258 (online) 


\section{Contents}

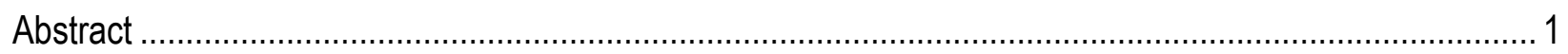

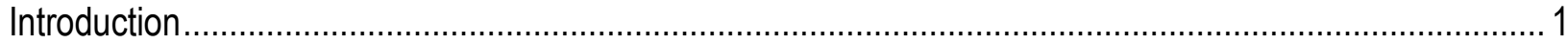

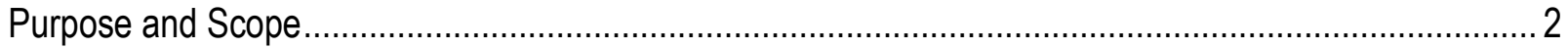

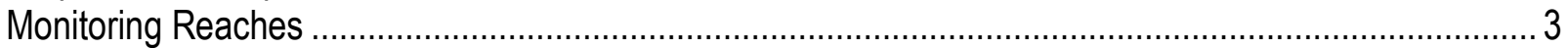

Linear Referencing and Units ................................................................................................... 3

Data Collection Methods and Dataset Access ............................................................................... 5

Continuous Temperature Sensors...........................................................................................

Continuous Temperature Data Access ……………………..................................................

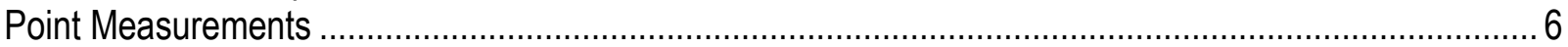

Point Measurement Data Access ............................................................................................. 9

Ongoing Temperature Data at Long-Term U.S. Geological Survey Sites .......................................... 10

Temperature Data by Monitoring Reach .......................................................................................... 11

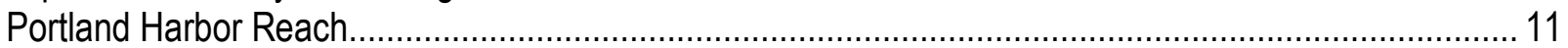

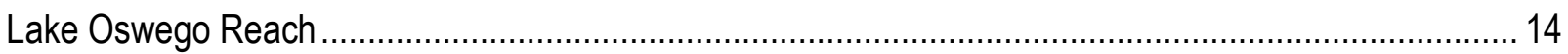

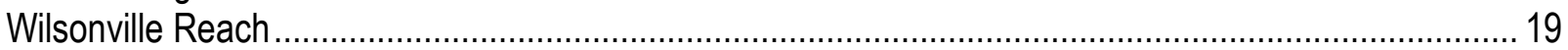

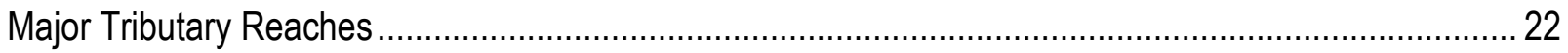

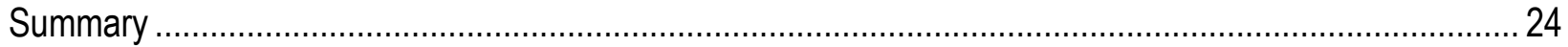

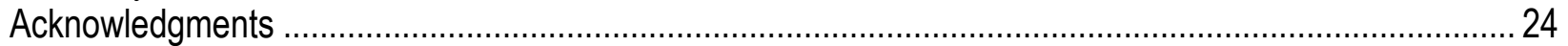

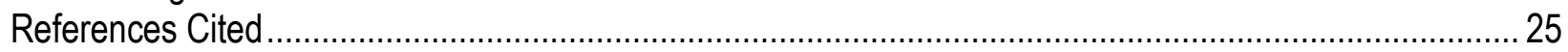

Appendix 1. Photographs of Tributaries with Continuous Temperature Sensors........................................ 27

\section{Figures}

Figure 1. Map showing locations of water temperature sensors and main-channel and tributary monitoring reaches in the lower Willamette River, northwestern Oregon, summers 2016 and 2017.

Figure 2. Graphs showing water temperature from U.S. Geological Survey (USGS) streamgages Willamette River at Portland (14211720) and Newberg (14197900); air temperature from the USGS streamgage Tualatin River at Oswego Dam (14207200); and dates of point measurement field trips in northwestern Oregon, summers 2016 and 2017.......................................................................... 8

Figure 3. Graphs showing water temperature of tributaries in the Portland Harbor Reach and in the Willamette River at Portland (USGS streamgage 14211720), northwestern Oregon, summer 2016 ........... 12 Figure 4. Maps showing water temperature point measurements for July 21, $2016(A)$, and August 31, $2016(B)$, in the Portland Harbor Reach, northwestern Oregon. .13

Figure 5. Graphs showing water temperature of tributaries in the Lake Oswego Reach and in the Willamette River at Portland (USGS streamgage 14211720), northwestern Oregon, summer 2016 Figure 6. Graphs showing water temperature of tributaries in the Lake Oswego Reach and in the Willamette River at Portland (USGS streamgage 14211720), northwestern Oregon, summer 2017 15

Figure 7. Maps showing water temperature point measurements for July 13-14, $2016(A)$, and September 1, $2016(B)$, in the Lake Oswego Reach, northwestern Oregon 16

Figure 8. Maps showing water temperature point measurements for June 27, 2017 (A), August 1, 2017 (B), and August 23, 2017 (C), in the Lake Oswego Reach, northwestern Oregon.. 
Figure 9. Graphs showing water temperature of tributaries in the Wilsonville Reach and in the Willamette River at Newberg (USGS streamgage 14197900), northwestern Oregon, summer 2017 ......... 20 Figure 10. Maps showing water temperature point measurements for June 28, $2017(A)$, August 2, $2017(B)$, and August 23, 2017 (C), in the Wilsonville Reach, northwestern Oregon.

Figure 11. Maps showing water temperature point measurements for the lower 2 kilometers $(\mathrm{km})$ of Johnson Creek on July $31(A)$, the lower $2.5 \mathrm{~km}$ of the Clackamas River on August $1(B)$, and the lower 1.5 $\mathrm{km}$ of the Molalla River on August 2 (C), northwestern Oregon, 2017.

\section{Tables}

Table 1. Continuous temperature sensors deployed in tributaries of the lower Willamette River, northwestern Oregon, summers 2016 and 2017.

Table 2. Dates and locations of point measurement field trips with reference to report figures of watertemperature point data, northwestern Oregon, summers 2016 and 2017.

\section{Conversion Factors}

U.S. customary units to International System of Units

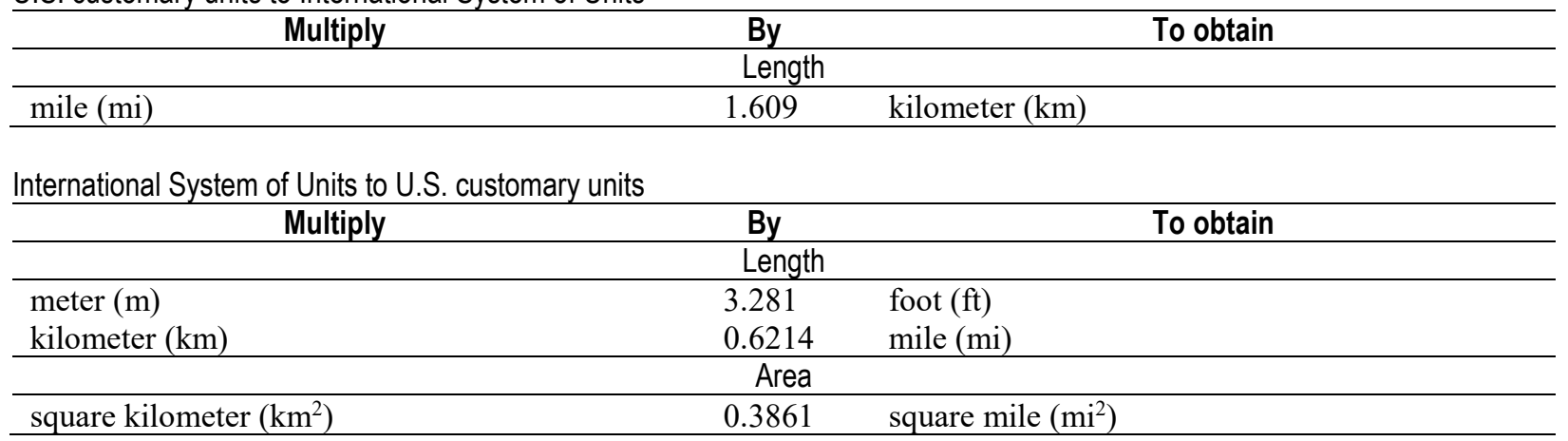

Temperature in degrees Celsius $\left({ }^{\circ} \mathrm{C}\right)$ may be converted to degrees Fahrenheit $\left({ }^{\circ} \mathrm{F}\right)$ as follows:

$$
{ }^{\circ} \mathrm{F}=\left(1.8 \times{ }^{\circ} \mathrm{C}\right)+32 \text {. }
$$

\section{Datums}

Horizontal coordinate information is referenced to the North American Datum of 1983 (NAD 83).

\section{Abbreviations}

GIS

ODEQ

NWIS

RM

7dADM

USGS geographic information system Oregon Department of Environmental Quality USGS National Water Information System River mile seven-day moving average of daily maximum U.S. Geological Survey 


\title{
Water Temperature in Tributaries, Off-Channel Features, and Main Channel of the Lower Willamette River, Northwestern Oregon, Summers 2016 and 2017
}

\author{
By Joseph F. Mangano, David R. Piatt, Krista L. Jones, and Stewart A. Rounds
}

\begin{abstract}
The U.S. Geological Survey collected continuous water-temperature data in select tributaries of the lowermost 80 kilometers (50 miles) of the Willamette River in northwestern Oregon, during summers 2016 and 2017. Point measurements of water temperature and water quality (dissolved oxygen, specific conductance, and $\mathrm{pH}$ ) also were collected at multiple locations and depths within the river and in the lower reaches of three major tributaries (Clackamas and Molalla Rivers, and Johnson Creek). These datasets were collected to identify potential locations of cold-water refuges for sensitive fish species, and to characterize daily, seasonal, and spatial variability in water conditions. These datasets may be useful for local municipalities that are required to identify cold-water refuges (as defined in State of Oregon water-quality standards) and determine approaches for protecting and enhancing these features as part of their Willamette River water-temperature Total Maximum Daily Load implementation plans. This report documents the data collection methods, provides summary graphs and maps of the water-temperature data, and outlines steps for accessing the data.
\end{abstract}

\section{Introduction}

Native cold-water fish may seek refuge in localized patches of cooler water-or cold-water refuges - during periods when main-channel river temperatures exceed their thermal tolerances (Dugdale and others, 2013). Cold-water refuges can occur in a variety of locations and scales, including off-channel areas (such as alcoves, side channels, and sloughs); tributary junctions; deep pools; or bank seeps (Torgersen and others, 2012). The distribution and persistence of cold-water refuges along a river network depend on the local streamflow and morphology of a river and its tributaries, and, therefore, can vary spatially and temporally within a river network (Torgersen and others, 2012; Dugdale and others, 2013).

The lower Willamette River provides migratory and rearing habitat for several evolutionarily significant units of anadromous salmonids listed as threatened by the Endangered Species Act (16 U.S.C. § 1531 et seq.) including Upper Willamette River spring Chinook salmon (Oncorhynchus tshawytscha) and winter steelhead (O. mykiss) that each spawn in tributaries of the Willamette River (Vile and Freisen, 2004; National Marine Fisheries Service, 2008). The Oregon Department of Environmental Quality (ODEQ) has set maximum water-temperature standards for stream reaches in Oregon, including the lower Willamette River, to protect certain life stages of these and other temperature-sensitive fishes. The ODEQ criteria are based on the 7-d moving average of the daily maximum (7dADM) water temperature. The lower $80 \mathrm{~km}(50 \mathrm{mi})$ of the Willamette River (downstream from Newberg, Oregon) was designated as "migration corridor use" with a 7dADM 
water-temperature criterion of $20.0^{\circ} \mathrm{C}$ year-round (Oregon Administrative Rule [OAR] 340-0410028(4)(d); Oregon Department of Environmental Quality, 2016a). Migration corridors also have a narrative standard for "cold-water refugia that are sufficiently distributed so as to allow salmon and steelhead migration without significant adverse effects from higher water temperatures elsewhere in the water body" (OAR 340-041-0028(4)(d), Oregon Department of Environmental Quality, 2016a). This narrative defines cold-water refugia as "those portions of a water body where or times during the diel temperature cycle when the water temperature is at least $2{ }^{\circ} \mathrm{C}$ colder than the daily maximum temperature of the adjacent well-mixed flow of the water body" (OAR 340-041-0002(10); Oregon Department of Environmental Quality, 2016b). Some water-management agencies along the lower Willamette River are required to map, protect, and enhance cold-water refuges as part of their Willamette River water-temperature Total Maximum Daily Load (TMDL) implementation plans.

\section{Purpose and Scope}

To date (2018), limited water-temperature and water-quality data have been collected to characterize water conditions and identify cold-water refuges in the lower Willamette River. Existing data include thermal infrared imagery surveys by the City of Portland in 2011 (City of Portland, 2014) and continuous water-temperature data collected by the U.S. Geological Survey (USGS) at the USGS Willamette River at Portland monitoring site (site 14211720, water-temperature period of record November 7, 1975, to present), among other sites in the reach (see section, "Ongoing Temperature Data at Long-Term U.S. Geological Survey Sites”). Water-temperature point measurements also were collected in conjunction with fish sampling in the lower Willamette River area (Oregon State University, 2018). Sufficient data were unavailable, however, to specifically map and characterize cold-water refuges; such a characterization would include more detailed data on water-temperature conditions spatially and with depth along the main channel and off-channel features of the lower Willamette River, or an assessment of water-temperature patterns and trends in selected tributaries to the lower Willamette River.

This study helps address knowledge gaps regarding cold-water refuges in the lower Willamette River by collecting data to identify, monitor, and characterize water temperature and some waterquality conditions in tributaries and off-channel areas of the lowermost $80 \mathrm{~km}(50 \mathrm{mi})$ of the Willamette River during summers 2016 and 2017. Continuous water-temperature data were collected in 12 tributaries in 2016 and in 10 tributaries in 2017. Water temperature and water-quality point measurements were collected at multiple locations and varying depths in the main channel and in offchannel features in 2016 and 2017. Additional water-temperature and water-quality measurements were made in 2017 in the lowermost $1.5-2.5 \mathrm{~km}$ of three major tributaries to the lower Willamette River (Clackamas and Molalla Rivers, and Johnson Creek). These continuous and point measurement datasets were published online at multiple outlets (see sections, "Continuous Temperature Data Access" and "Point Measurement Data Access") but with minimal documentation besides the required metadata for each dataset. This report more thoroughly documents the methods of water temperature data collection; outlines steps for accessing the datasets; and provides published results, graphs, and maps of the water temperature data. Although other water-quality parameters critical for fish (such as $\mathrm{pH}$ or concentrations of dissolved oxygen) were collected ancillary to much of the point watertemperature data, those parameters are not considered here. Separate analysis, not included in this report, would be needed to evaluate whether the measurement sites meet the criteria for cold-water refuges and to determine appropriate management strategies for enhancing or preserving habitat conditions at those sites. 


\section{Monitoring Reaches}

This study focused on water temperature measurements in select reaches along the lowermost $80 \mathrm{~km}$ (50 mi) of the Willamette River between Newberg, Oregon, and the Columbia River (fig. 1). Monitoring reaches for this study included the following:

- Portland Harbor Reach - The main-channel Willamette River from the Fremont Bridge (Interstate 405) in Portland, Oregon to the confluence of the Willamette River with the Columbia River (river mile [RM] 0-10).

- Lake Oswego Reach - The main-channel Willamette River near the City of Lake Oswego. In 2016, the monitoring reach extended from Willamette Falls to the upstream end of Ross Island near Portland (RM 16-26). In 2017, the monitoring reach was much shorter and only included that part of the river that borders the City of Lake Oswego (RM 20-22).

- Wilsonville Reach - The main-channel Willamette River that borders the City of Wilsonville (RM 37-40); this monitoring reach is within the pooled part of the Willamette River between Willamette Falls and Newberg, Oregon.

- Major Tributary Reaches - The lower 1.5, 2.5, and $1.5 \mathrm{~km}$ of the Molalla and Clackamas Rivers, and Johnson Creek, respectively.

\section{Linear Referencing and Units}

Locations of reaches and sites along the main-channel Willamette River are referenced to river miles from associated USGS topographic maps (https://www.usgs.gov/products/maps/topo-maps). All other units in this report and associated data releases, including distances along tributaries, are reported in metric units. 


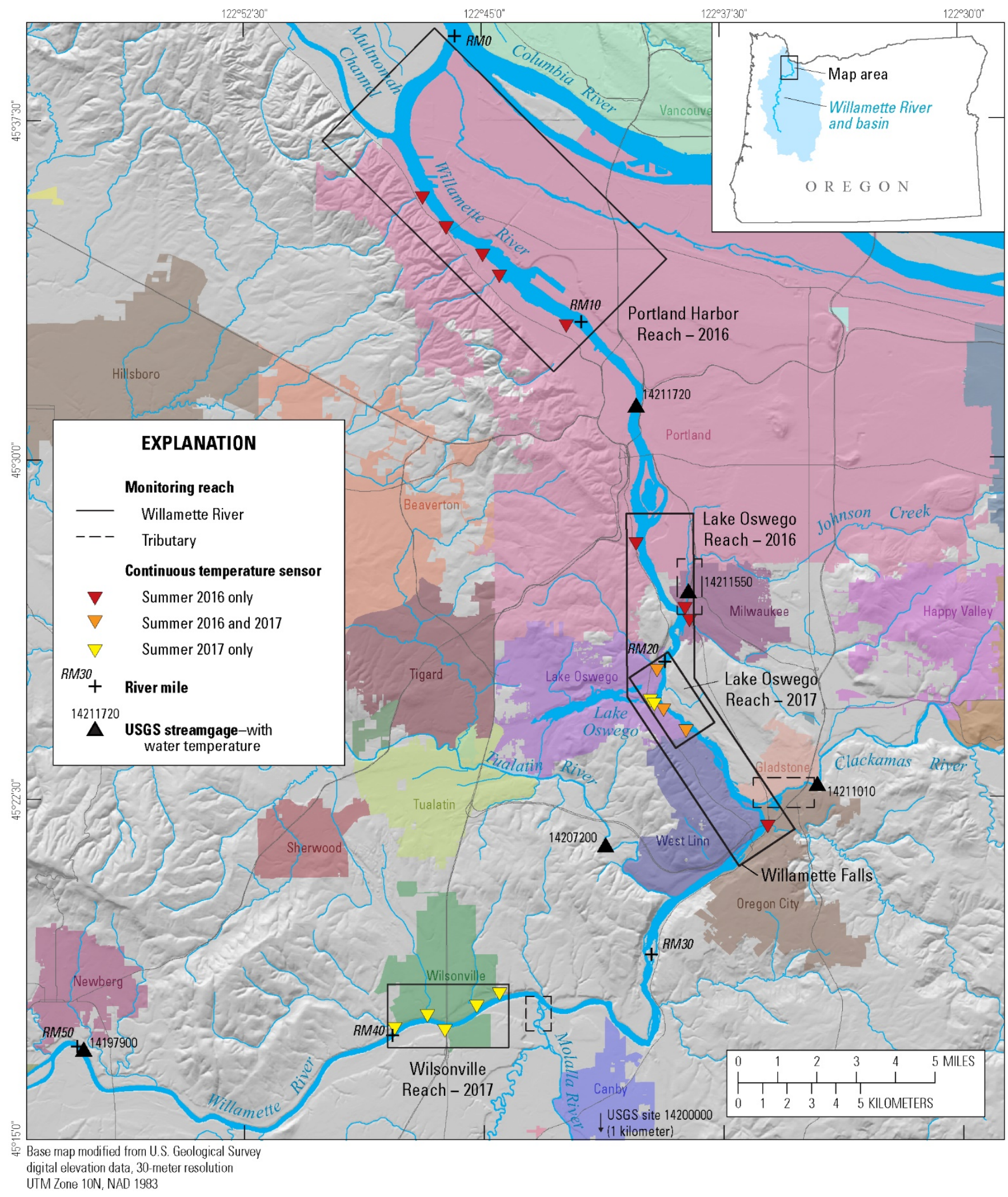

Figure 1. Map showing locations of water temperature sensors and main-channel and tributary monitoring reaches in the lower Willamette River, northwestern Oregon, summers 2016 and 2017. 


\section{Data Collection Methods and Dataset Access}

\section{Continuous Temperature Sensors}

Onset ${ }^{\circledR}$ Hobo $^{\circledR}$ continuous water-temperature sensors (model U22-001) were deployed to collect data every $15 \mathrm{~min}$ in tributaries to the lower Willamette River in summers 2016 and 2017 (table 1; fig. 1). Water-temperature sensors were checked in accordance with USGS standard protocols (Wagner and others, 2006). Sensors were attached with wire rope to a secure object on the riverbank (such as a tree trunk, root, or earth anchor) and then the sensors were weighted and placed in hidden locations within or as close as possible to the main tributary flow. Deployment locations were selected to be as close as possible to the Willamette River, but out of any backwater caused by the Willamette River. Upon retrieval, data were reviewed following USGS standards, resulting in the removal of some data points that were collected when the sensor was dry because of changing river stage in the Willamette River or tributary. Periods when tributary temperatures were affected by backwater from the Willamette River were not removed or specifically identified in this report. To identify these periods, comparison is needed between tributary temperature and main-channel temperature at times when the Willamette River stage is high. Comparable main-channel temperature is shown in all continuous sensor temperature plots in this report. Backwater conditions will be evident when tributary temperatures converge with main-channel temperatures.

In 2016, 12 continuous temperature sensors were deployed in the Lake Oswego $(n=7)$ and Portland Harbor $(\mathrm{n}=5)$ monitoring reaches. They were installed in mid-July and removed by midOctober. In 2017, 10 continuous temperature sensors were deployed in the Lake Oswego ( $\mathrm{n}=5)$ and Wilsonville $(n=5)$ monitoring reaches. They were installed in early June and removed in late October or December as river flow conditions allowed. The monitored tributaries varied greatly in drainage basin area, ranging from less than 1 to nearly $140 \mathrm{~km}^{2}$ (table 1). The tributaries also had different riparian vegetation, channel width, and streamflow conditions at the location of sensor installations, as documented by site photographs (appendix 1).

\section{Continuous Temperature Data Access}

The continuous water-temperature data from this study can be accessed in multiple ways, always referenced to the USGS National Water Information System (NWIS) site number (table 1). The first and most definitive option is to access the data through NWIS (U.S. Geological Survey, 2018b), which has a public internet interface at https:/waterdata.usgs.gov/or/nwis. The same data can be accessed through USGS Water Services (U.S. Geological Survey, 2018c), which serve information to the dataRetrieval and other USGS R packages available at https://owi.usgs.gov/R/ (U.S. Geological Survey, 2018d). At this time (2018), another good way to access and visualize the continuous watertemperature data is through the USGS Oregon Data Grapher at https://or.water.usgs.gov/grapher/ (U.S. Geological Survey, 2018e), a set of tools that allows users to interactively explore and build graphs of USGS time-series data. Sites from this study are grouped in the Data Grapher as "Willamette River off-channel sites" under the "Basin" menu. 
Table 1. Continuous temperature sensors deployed in tributaries of the lower Willamette River, northwestern Oregon, summers 2016 and 2017.

[Drainage areas were derived using StreamStats (U.S. Geological Survey, 2018a). Easting and Northing: Coordinates in North American Datum of 1983 Universal Transverse Mercator Zone 10N. Abbreviations: NWIS, National Water Information System; $\mathrm{RM}$, river mile; $\mathrm{km}^{2}$, square kilometer; <, less than]

\begin{tabular}{|c|c|c|c|c|c|c|c|c|}
\hline RM & Site name & NWIS site No. & Easting & Northing & $\begin{array}{c}\text { Record } \\
\text { start date }\end{array}$ & $\begin{array}{l}\text { Record } \\
\text { end date }\end{array}$ & $\begin{array}{c}\text { Monitoring } \\
\text { reach }\end{array}$ & $\begin{array}{c}\text { Drainage area } \\
\left(\mathrm{km}^{2}\right)\end{array}$ \\
\hline \multicolumn{9}{|c|}{ Summer 2016} \\
\hline 4.9 & $\begin{array}{l}\text { Unnamed tributary to } \\
\text { Willamette River at } \\
\text { RM } 4.9 \text { on left bank }\end{array}$ & 453548122465100 & 517083 & 5049273 & $7-21$ & $10-18$ & Portland Harbor & ${ }^{1} 1.9$ \\
\hline 5.9 & $\begin{array}{l}\text { Unnamed tributary to } \\
\text { Willamette River at } \\
\text { RM 5.9 on left bank }\end{array}$ & 453509122460800 & 518039 & 5048045 & $7-21$ & $10-18$ & Portland Harbor & ${ }^{1} 0.9$ \\
\hline 6.9 & $\begin{array}{l}\text { Doane Creek at mouth, } \\
\text { at Portland }\end{array}$ & 453432122445800 & 519541 & 5046920 & $7-21$ & $10-18$ & Portland Harbor & ${ }^{1} 3.3$ \\
\hline 7.8 & $\begin{array}{l}\text { Saltzman Creek at mouth, } \\
\text { at Portland }\end{array}$ & 453405122442800 & 520194 & 5046092 & $7-21$ & $10-18$ & Portland Harbor & ${ }^{1} 4.4$ \\
\hline 9.8 & $\begin{array}{l}\text { Balch Creek at mouth, } \\
\text { at Portland }\end{array}$ & 453258122422100 & 522966 & 5044025 & $7-21$ & $10-18$ & Portland Harbor & ${ }^{1} 9.5$ \\
\hline 16.2 & $\begin{array}{l}\text { Stephens Creek at mouth, } \\
\text { at Portland }\end{array}$ & 452808122401100 & 525821 & 5035096 & $7-14$ & $10-06$ & Lake Oswego & 3.2 \\
\hline 18.4 & $\begin{array}{l}\text { Johnson Creek near mouth, } \\
\text { at Milwaukie }\end{array}$ & 452642122383600 & 527897 & 5032454 & $7-14$ & $10-06$ & Lake Oswego & 138.8 \\
\hline 18.5 & $\begin{array}{l}\text { Kellogg Creek at mouth, } \\
\text { below Kellogg Dam }\end{array}$ & 452630122383200 & 527971 & 5032092 & $7-14$ & $10-06$ & Lake Oswego & 42.5 \\
\hline 20.1 & $\begin{array}{l}\text { Tryon Creek near mouth, } \\
\text { at Lake Oswego }\end{array}$ & 452521122392900 & 526746 & 5029949 & $7-13$ & $10-06$ & Lake Oswego & 17.5 \\
\hline 21.3 & $\begin{array}{l}\text { Glenmorrie Creek at mouth, } \\
\text { at Lake Oswego }{ }^{2}\end{array}$ & 452428122392000 & 526945 & 5028317 & $7-13$ & $10-06$ & Lake Oswego & ${ }^{3}<1$ \\
\hline 22.0 & $\begin{array}{l}\text { Arbor Creek at mouth, } \\
\text { at Lake Oswego }\end{array}$ & 452360122383800 & 527873 & 5027441 & $7-13$ & $10-06$ & Lake Oswego & 1.9 \\
\hline 25.5 & $\begin{array}{l}\text { Abernathy Creek near mouth, } \\
\text { at Oregon City }\end{array}$ & 452153122360500 & 531206 & 5023558 & $7-13$ & $10-06$ & Lake Oswego & 85.2 \\
\hline \multicolumn{9}{|c|}{ Summer 2017} \\
\hline 20.1 & $\begin{array}{l}\text { Tryon Creek near mouth, } \\
\text { at Lake Oswego }{ }^{2}\end{array}$ & 452521122392900 & 526655 & 5029956 & $4-27$ & $9-20$ & Lake Oswego & 17.5 \\
\hline 21.0 & $\begin{array}{l}\text { Oswego Creek in large pool, } \\
\text { at Lake Oswego }\end{array}$ & 452439122394200 & 526489 & 5028636 & $4-27$ & $9-27$ & Lake Oswego & ${ }^{4} 19.8$ \\
\hline 21.0 & $\begin{array}{l}\text { Oswego Creek near dam } \\
\text { outlet, at Lake Oswego }\end{array}$ & 452439122394600 & 526383 & 5028650 & $4-27$ & $10-26$ & Lake Oswego & ${ }^{4} 19.6$ \\
\hline 21.3 & $\begin{array}{l}\text { Glenmorrie Creek at mouth, } \\
\text { at Lake Oswego }{ }^{2}\end{array}$ & 452428122392000 & 526909 & 5028286 & $4-27$ & $10-26$ & Lake Oswego & ${ }^{3}<1$ \\
\hline 22.0 & $\begin{array}{l}\text { Arbor Creek at mouth, } \\
\text { at Lake Oswego }{ }^{2}\end{array}$ & 452360122383800 & 527856 & 5027450 & $4-27$ & $10-19$ & Lake Oswego & 1.9 \\
\hline 36.9 & $\begin{array}{l}\text { Willow Creek near mouth, } \\
\text { at Wilsonville }\end{array}$ & 451807122443100 & 520229 & 5016534 & $6-08$ & $10-26$ & Wilsonville & 2.2 \\
\hline 37.6 & $\begin{array}{l}\text { Boeckman Creek near mouth, } \\
\text { at Wilsonville }\end{array}$ & 451753122451200 & 519341 & 5016059 & $6-08$ & $12-19$ & Wilsonville & 6.7 \\
\hline 38.7 & $\begin{array}{l}\text { Unnamed creek near mouth, } \\
\text { at RM } 38.7 \text { near } \\
\text { Wilsonville }\end{array}$ & 451726122461800 & 517904 & 5015262 & $6-02$ & $12-19$ & Wilsonville & 8.3 \\
\hline 39.0 & $\begin{array}{l}\text { Coffee Lake Creek near } \\
\text { mouth, at Wilsonville }\end{array}$ & 451740122464500 & 517316 & 5015693 & $6-02$ & $10-26$ & Wilsonville & 22.2 \\
\hline 39.9 & $\begin{array}{l}\text { Corral Creek near mouth, } \\
\text { at Wilsonville }\end{array}$ & 451725122474400 & 516018 & 5015227 & $6-02$ & $10-26$ & Wilsonville & 29.3 \\
\hline
\end{tabular}

${ }^{1}$ Stream is culverted under Portland Harbor industrial area and may not accurately represent the actual drainage area.

${ }^{2}$ Repeat site in 2016 and 2017.

${ }^{3}$ Stream too small for accurate representation in StreamStats.

${ }^{4}$ Stream includes Lake Oswego and diversion influence from the Tualatin River. 


\section{Point Measurements}

Point measurements of water temperature and water-quality parameters (dissolved oxygen, specific conductance, and pH) were taken multiple times in summers 2016 and 2017 (fig. 2; table 2). Point measurements were made with a $\mathrm{YSI}^{\mathrm{TM}}$ 6-series water-quality monitor (equipped with water temperature, specific conductance, dissolved oxygen, and pH sensors), or a YSI ${ }^{\mathrm{TM}}$ EcoSense EC300A meter (which only measured water temperature and specific conductance). Sensors were calibrated prior to each measurement trip following USGS protocols (Wagner and others, 2006) and manufacturer instructions. Measurements were made along cross-sectional transects and depths of the main-channel Willamette River, in tributaries, and at other locations of interest. All point measurements included location, time, approximate depth below water surface, and the parameters recorded. This report focuses on the water-temperature part of these datasets. The data for the other water-quality parameters (dissolved oxygen, specific conductance, and $\mathrm{pH}$ ) along with temperature are documented and available in the original data releases online (see section, "Point Measurement Data Access").

Water-temperature point measurements have been grouped into three feature types to facilitate comparisons:

1. Main channel-Measurement taken within the well-mixed main-channel flow of the Willamette River. Measurements typically are measured at multiple depths in areas of deep water.

2. Tributary - A single measurement collected within the well-mixed flow of a tributary, near the mouth.

3. Other feature-Measurements taken in other river features, including alcoves, seeps, tributary plumes, or other mixing zones where it was difficult to determine the exact type or origin of water being measured. See the original data releases (Mangano and others, 2017; Piatt and others, 2018) for exact subclasses and additional descriptions of these feature types.

Each measurement point included the measurement of depth below the water surface. For this report, depths were classified into three categories based on the location of a point in the water column:

1. Surface-Measurements at or near the surface of the water column; no deeper than $0.5 \mathrm{~m}$.

2. Bottom-Measurements on or near the bottom of the water column; actual depth varies because of variation in channel bathymetry.

3. Tributary-Measurements within the well-mixed tributary streamflow with no specific depth reported because of the small size of most tributaries.

Some point measurement locations included measurements at intermediate depths in the water column; these are not included in this report but are available in the original datasets along with absolute depth measurements for all point measurements. 

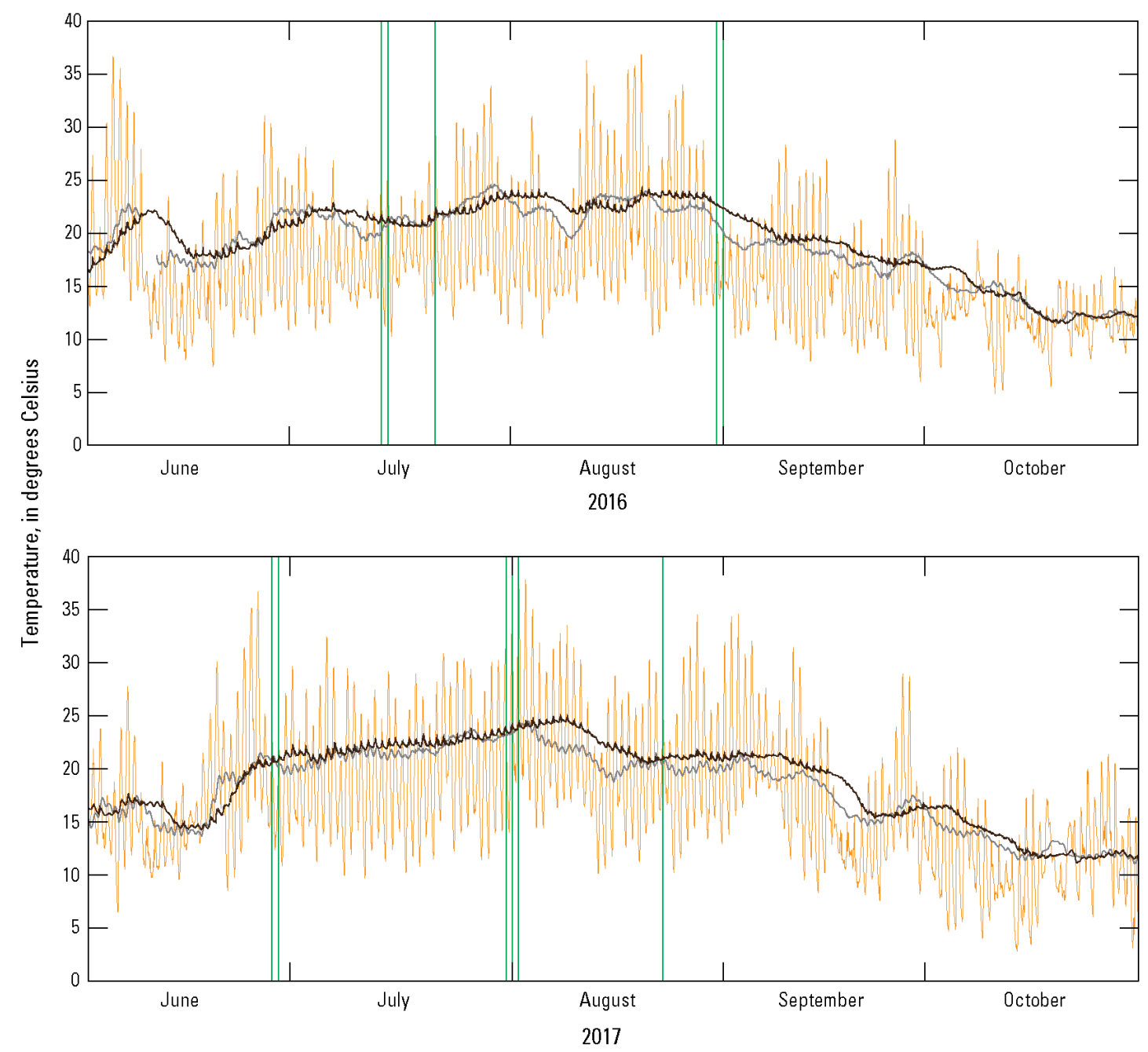

EXPLANATION

Water temperature at Willamette River at Portland (14211720)

— Water temperature at Willamette River at Newberg (14197900)

_ Air temperature at Tualatin River at Oswego Dam, near West Linn (14207200)

| Date of point measurement field trip

Figure 2. Graphs showing water temperature from U.S. Geological Survey (USGS) streamgages Willamette River at Portland (14211720) and Newberg (14197900); air temperature from the USGS streamgage Tualatin River at Oswego Dam (14207200); and dates of point measurement field trips in northwestern Oregon, summers 2016 and 2017. See table 2 for locations of point measurement field trips. 
Table 2. Dates and locations of point measurement field trips with reference to report figures of watertemperature point data, northwestern Oregon, summers 2016 and 2017.

\begin{tabular}{|c|c|c|}
\hline Monitoring reach & Date & Figure \\
\hline \multicolumn{3}{|c|}{ Summer 2016} \\
\hline Portland Harbor & July 21 & Figure $4 A$ \\
\hline Portland Harbor & August 31 & Figure $4 B$ \\
\hline Lake Oswego & July 13 and 14 & Figure $7 A$ \\
\hline Lake Oswego & September 1 & Figure $7 B$ \\
\hline \multicolumn{3}{|c|}{ Summer 2017} \\
\hline Lake Oswego & June 27 & Figure $8 A$ \\
\hline Lake Oswego & August 1 & Figure $8 B$ \\
\hline Lake Oswego & August 23 & Figure $8 C$ \\
\hline Wilsonville & June 28 & Figure $10 A$ \\
\hline Wilsonville & August 2 & Figure $10 B$ \\
\hline Wilsonville & August 23 & Figure $10 C$ \\
\hline Tributary_Johnson Creek & July 31 & Figure $11 A$ \\
\hline Tributary_Clackamas River & August 1 & Figure $11 B$ \\
\hline Tributary-Molalla River & August 2 & Figure $11 C$ \\
\hline
\end{tabular}

\section{Point Measurement Data Access}

Point measurements of water temperature and water quality from this study were published in two USGS data releases, separated by year:

- Point measurement data from 2016 were published with other similar Willamette River datasets as part of the USGS data release, "Point measurements of temperature and water quality in main-channel and off-channel features of the Willamette River, 2015-16" (Mangano and others, 2017), at https://doi.org/10.5066/F7VQ315D.

- Point measurement data from 2017 were published in the USGS data release, "Point measurements of temperature and water quality in the main channel and off-channel features of the lower reaches of the Willamette River, Clackamas River, Molalla River, and Johnson Creek, 2017" (Piatt and others, 2018), at https://doi.org/10.5066/F7KH0MJP.

Viewing and exploring the point measurement data are best done in a geographic information system (GIS) by plotting the sample points by their respective Easting and Northing coordinates (Universal Transverse Mercator Zone $10 \mathrm{~N}$ ), although the data also are available as tables in the data releases. Note that locations with multiple depths will plot in the same location in a GIS application, stacked on top of each other. 


\section{Ongoing Temperature Data at Long-Term U.S. Geological Survey Sites}

The USGS maintains streamgages and other data-collection sites along the lowermost $80 \mathrm{~km}$ of the Willamette River and in some of its major tributaries within that reach (fig. 1). Data from these sites provide useful comparisons to local river conditions (data available at https://waterdata.usgs.gov/or/nwis).

Reference sites recording stream temperature in the Oregon study reaches include:

- USGS 14211720, Willamette River at Portland;

- USGS 14197900, Willamette River at Newberg;

- USGS 14211010, Clackamas River near Oregon City;

- USGS 14211550, Johnson Creek at Milwaukie; and

- USGS 14200000, Molalla River near Canby.

A reference site recording air temperature in the Oregon study reaches includes USGS 14207200, Tualatin River at Oswego Dam, near West Linn. 


\section{Temperature Data by Monitoring Reach}

\section{Portland Harbor Reach}

Water-temperature measurements in the 16-km long Portland Harbor Reach were only collected in summer 2016. Graphs of continuous water-temperature readings from the tributaries are shown in figure 3. Locations and water-temperature values of point measurements are shown for July 21 and August 31, 2016, in figure 4.

Tributaries with continuous temperature sensors in the Portland Harbor Reach flow through a series of culverts and pipes under the northwestern Portland industrial area that flanks the west bank of the Willamette River throughout the reach (fig. 4; appendix 1). Many of the streams originate in the steep, forested Tualatin Mountains west of the industrial area before entering a network of underground culverts that eventually flow into the Willamette River. Water temperatures in Balch and Saltzman Creeks were often near or greater than $20^{\circ} \mathrm{C}$ in July-August and as much as $25^{\circ} \mathrm{C}$ on some days (fig. 3). Diel variation in these two creeks was large, commonly greater than $4{ }^{\circ} \mathrm{C}$ each day. In contrast, water temperatures in the other three tributaries in this reach were consistently less than 18 ${ }^{\circ} \mathrm{C}$, with relatively low diel temperature variations. Water temperatures in all tributaries became noticeably cooler as summer transitioned to autumn, but particularly when several of the tributaries likely became inundated with Willamette River water (for example, see the photograph of Balch Creek in appendix 1 and similar water temperature readings between the tributary and main channel in figure 3 ). Sudden changes in water temperature in the unnamed tributary at river mile 5.9 during October correspond to autumn rain events, which are less noticeable in the other tributaries.

Main-channel point-temperature measurements ranged from 24.3 to $22.2^{\circ} \mathrm{C}$ in the Portland Harbor Reach (fig. 4). The main channel at some locations in the Portland Harbor Reach can thermally stratify in summer, and warmer Willamette River water also can float on top of cooler backwatered Columbia River water during periods of strong tidal forcings in summer (Hines and others, 1977). Measurements from this study, however, showed that sites in the Portland Harbor Reach tended to be relatively well mixed thermally, with differences in water temperature between the river surface and bottom usually less than $0.3{ }^{\circ} \mathrm{C}$. The only locations with cooler main-channel temperatures were measured near tributary inputs, where the main channel would sometimes be slightly cooler at depth, perhaps indicating a cool and plunging plume of tributary water input. For example, on July 21, 2016, the main channel measurement near Balch Creek was $24.0^{\circ} \mathrm{C}$ at the surface, but $21.3{ }^{\circ} \mathrm{C}$ on the river bottom. Point measurements also were taken in the 3-4 tributaries in the Swan Island Area in July and August 2016 (fig. 4). In July 2016, water temperature point measurements of these small tributaries ranged from 18.5 to $27.0^{\circ} \mathrm{C}$; in late August 2016, the temperatures ranged from 16.8 to $22.3^{\circ} \mathrm{C}$. Although some of these tributaries had cooler temperatures in August, their contributing flows likely were small, given their small drainage areas. Point measurements also were made in the Multnomah Channel and near the confluence of the Columbia Slough with the Willamette River in August 2016. Temperatures were $23.0{ }^{\circ} \mathrm{C}$ at the Multnomah Channel measurement location, and $21.9{ }^{\circ} \mathrm{C}$ in the Columbia Slough near its mouth (fig. 4). The time of day when point-temperature measurements were taken likely has an influence on measured water temperature values and ranges, which was not systematically accounted for in this report. 


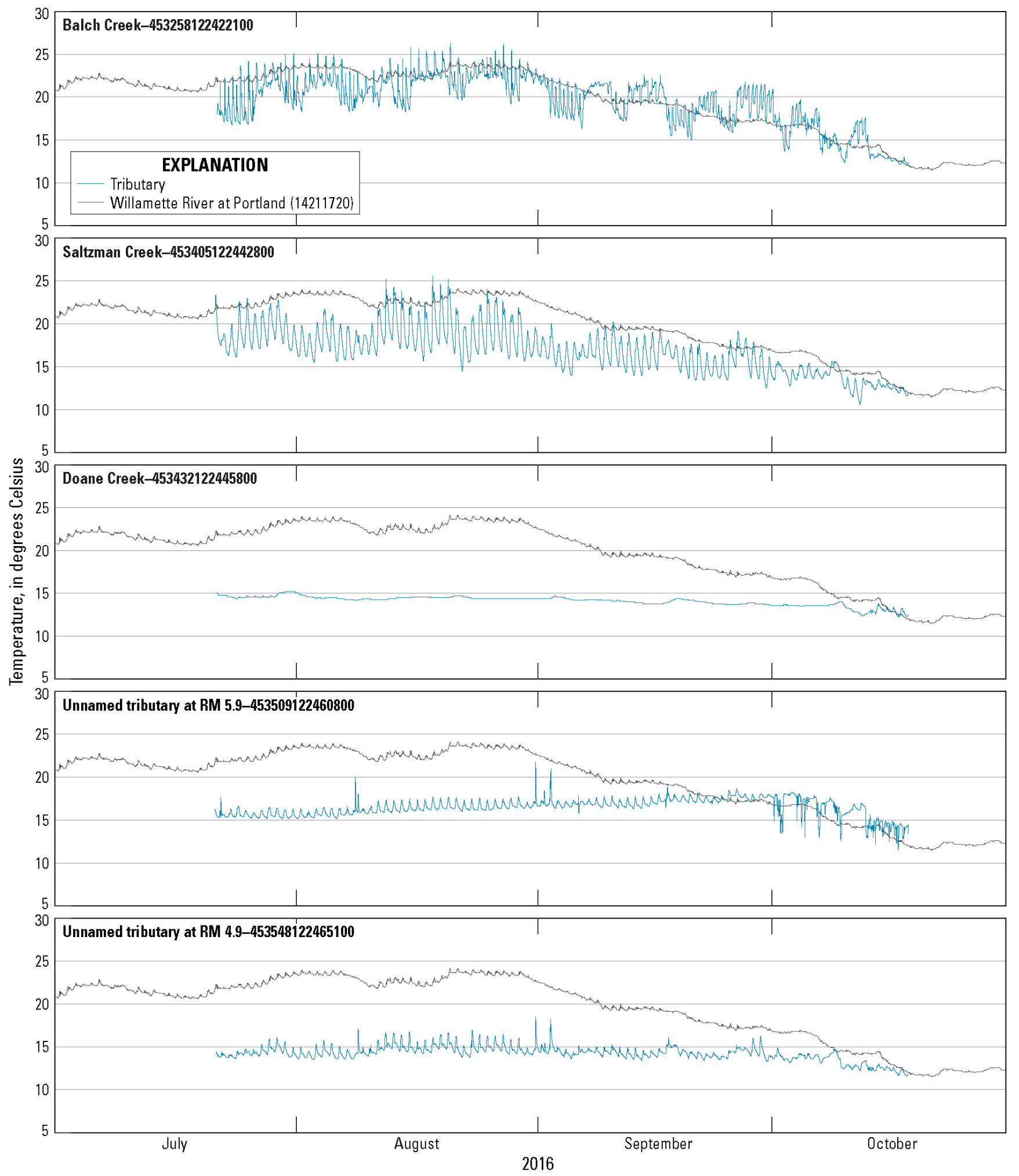

Figure 3. Graphs showing water temperature of tributaries in the Portland Harbor Reach and in the Willamette River at Portland (USGS streamgage 14211720), northwestern Oregon, summer 2016. 


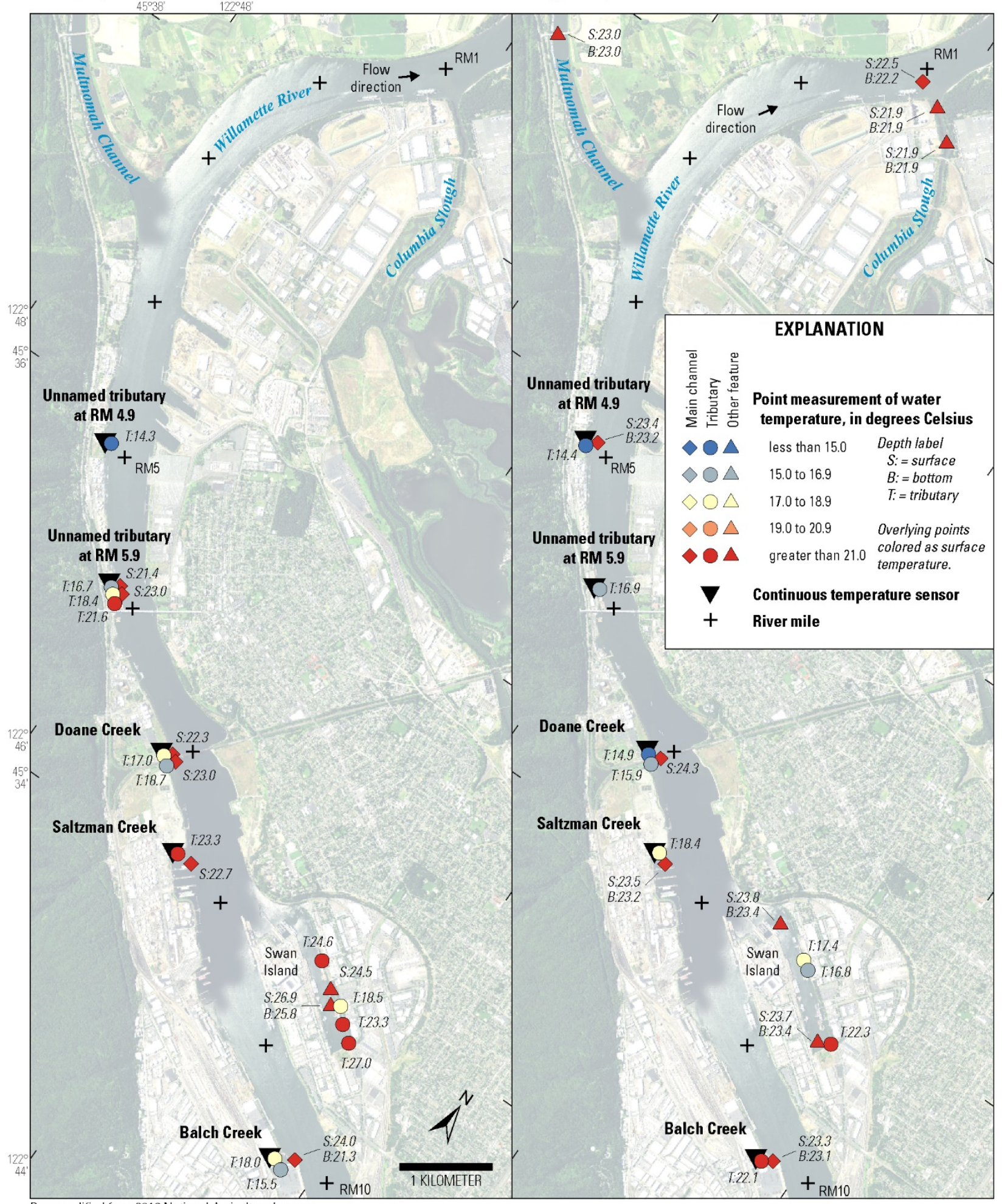

Base modified from 2016 National Agriculture Imagery Program orthophotographs overlaying lidar topography UTM Zone 10N, NADQ3

Figure 4. Maps showing water temperature point measurements for July 21, $2016(A)$, and August 31, $2016(B)$, in the Portland Harbor Reach, northwestern Oregon. 


\section{Lake Oswego Reach}

Water temperature measurements in the Lake Oswego Reach were collected along the 16-km long reach in summer 2016 and along the shorter 4-km long reach in 2017. Water temperature readings from continuous temperature sensors are plotted for summer 2016 in figure 5 and for summer 2017 in figure 6. Locations and water-temperature values of point measurements are shown for July 13 and 14, and September 1, 2016, in figure 7; and for June 27, and August 8 and 23, 2017, in figure 8.

Most tributaries with continuous temperature sensors in the Lake Oswego Reach were cooler than the Willamette River during most of each summer monitoring period, except for Oswego and Kellogg Creeks, both of which are downstream of dams (figs. 5-6). Water temperatures in Kellogg Creek often were cooler, but sometimes were warmer than the Willamette River in summer 2016, whereas Oswego Creek was consistently warmer than the main channel during the latter one-half of summer 2017. Diel fluctuations in tributaries ranged from nearly $5{ }^{\circ} \mathrm{C}$ in Johnson and Arbor Creeks to only $1{ }^{\circ} \mathrm{C}$ in Abernathy Creek. The sensor at the "Oswego Creek, in pool" site was measuring mostly Willamette River water, with additional warming at times. Somewhat consistent seasonal and weekly patterns in tributary water temperatures likely were owing to normal variations in the heat budgets of the streams caused by weather patterns and the changing seasons, as indicated by the measured air temperatures; see, for example, the warmer period of August 12-22, 2016 (figs. 2 and 5).

The lower Willamette River in the Lake Oswego Reach is largely confined laterally by bedrock and lacks the geomorphic processes that create many types of cold-water refuges supplied by hyporheic flow. Therefore, point measurements of water temperature and water-quality parameters in this reach focused on tributaries, locations near mapped faults along the main channel (Ma and others, 2009), and the quantification of spatial variability in river temperatures with depth and laterally across the channel. Point measurements indicated that many of the tributaries on the western side of the river were cooler than $17^{\circ} \mathrm{C}$, although these tributaries can vary greatly in drainage area and streamflow (figs. 7-8; table 1). There are fewer tributaries entering the Willamette River along its eastern bank in the Lake Oswego Reach compared with the western side; the eastern side tributaries were typically warmer than western side tributaries, ranging from 18.0 to $25.6^{\circ} \mathrm{C}$. Exploratory water-temperature readings were taken along the riverbed and riverbanks near mapped faults in this reach, but areas of noticeable temperature differences were not identified; not all exploratory measurements around mapped faults were recorded and mapped except at select transects and points.

During each sampling trip, Willamette River water temperatures showed minimal variation spatially or with depth throughout the Lake Oswego Reach (figs. 7-8). At locations as deep as $25 \mathrm{~m}$ along the main channel (cross section near RM 21.1 on September 1, 2016, fig. 7), the water was well mixed with temperatures consistently about $21.9^{\circ} \mathrm{C}$ throughout the water column. Slightly cooler water temperatures were noticeable at the river bottom of the main channel close to some colder tributary junctions, such as near Tryon Creek on July 13, 2016 (fig. 7A) and August 8, 2017 (fig. 8B). Water temperatures near the mouth of Tryon Creek were $0.3-2.3^{\circ} \mathrm{C}$ cooler than in the main channel of the Willamette River on those sampling trips. The time of day when point-temperature measurements were taken likely has an influence on measured water temperature values and ranges, which was not systematically accounted for in this report. 


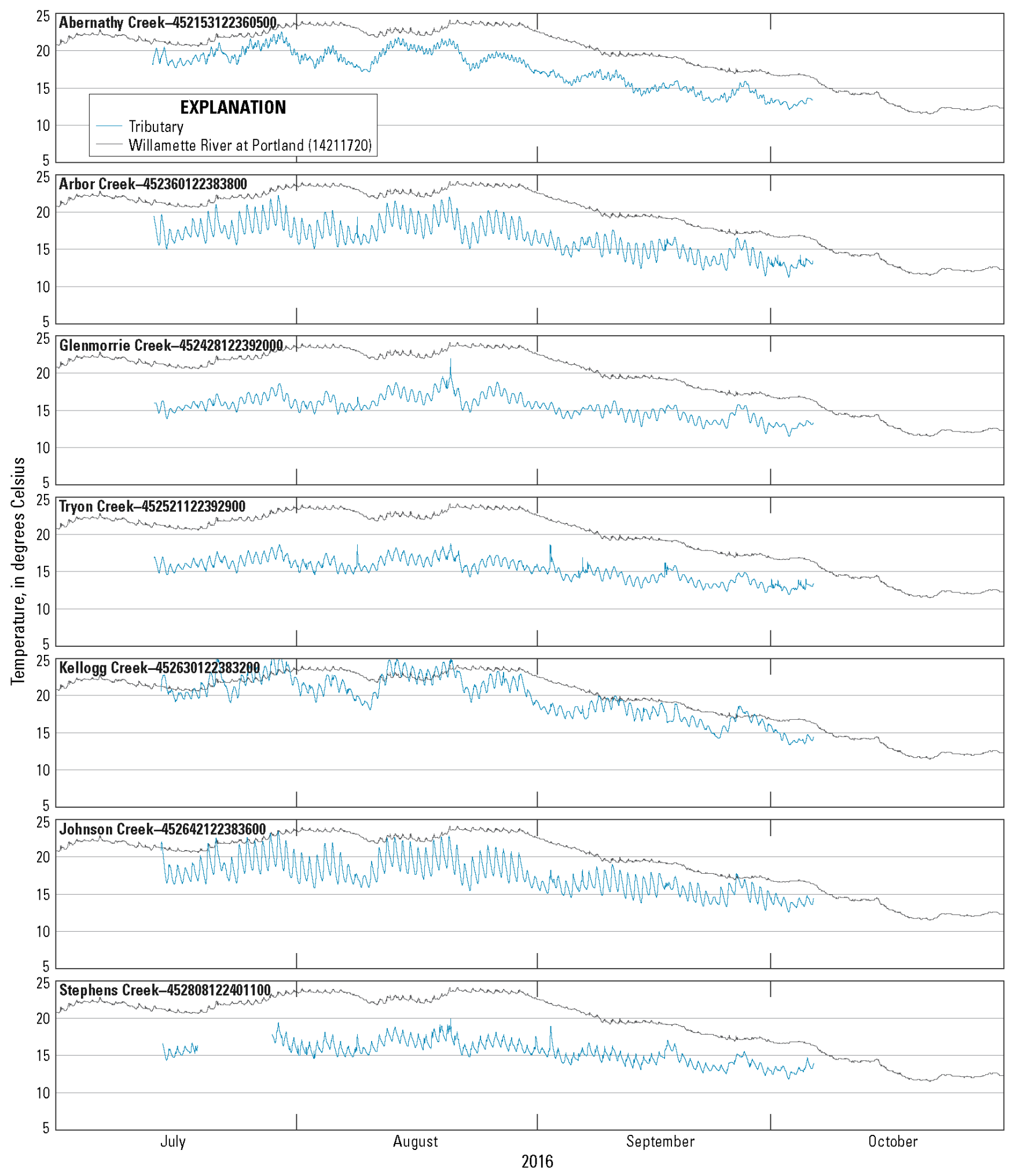

Figure 5. Graphs showing water temperature of tributaries in the Lake Oswego Reach and in the Willamette River at Portland (USGS streamgage 14211720), northwestern Oregon, summer 2016. 


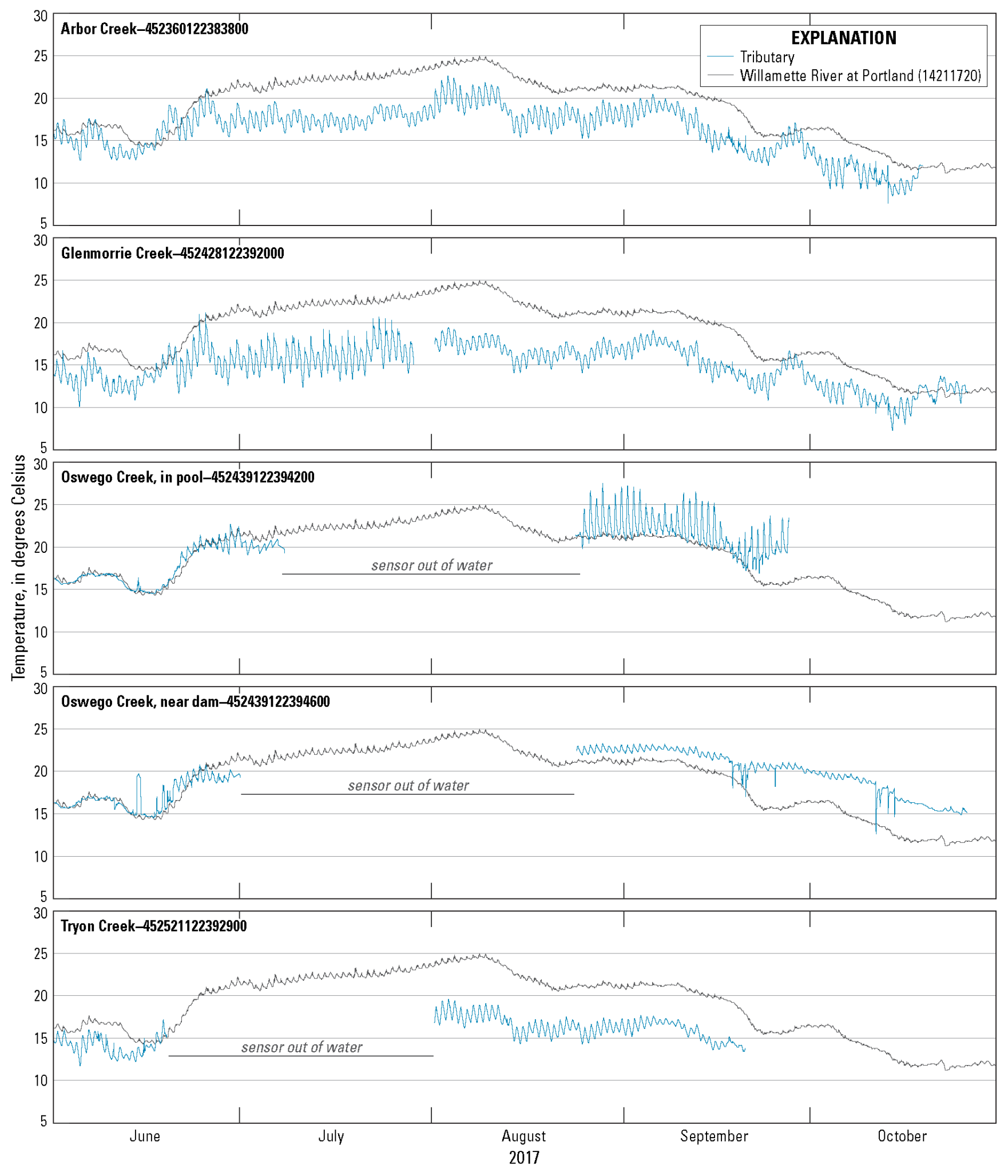

Figure 6. Graphs showing water temperature of tributaries in the Lake Oswego Reach and in the Willamette River at Portland (USGS streamgage 14211720), northwestern Oregon, summer 2017. 


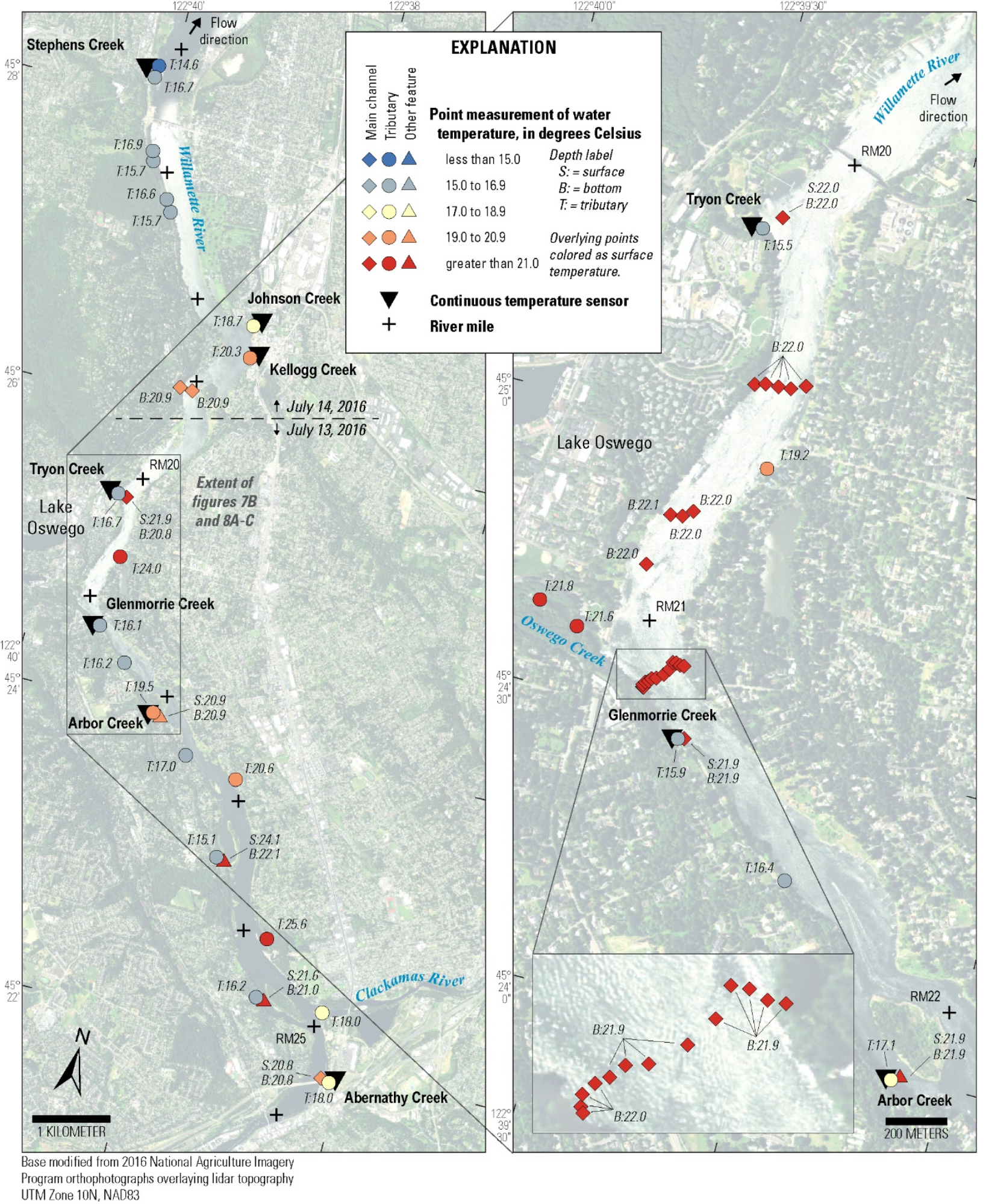

Figure 7. Maps showing water temperature point measurements for July 13-14, $2016(A)$, and September 1 , $2016(B)$, in the Lake Oswego Reach, northwestern Oregon. 


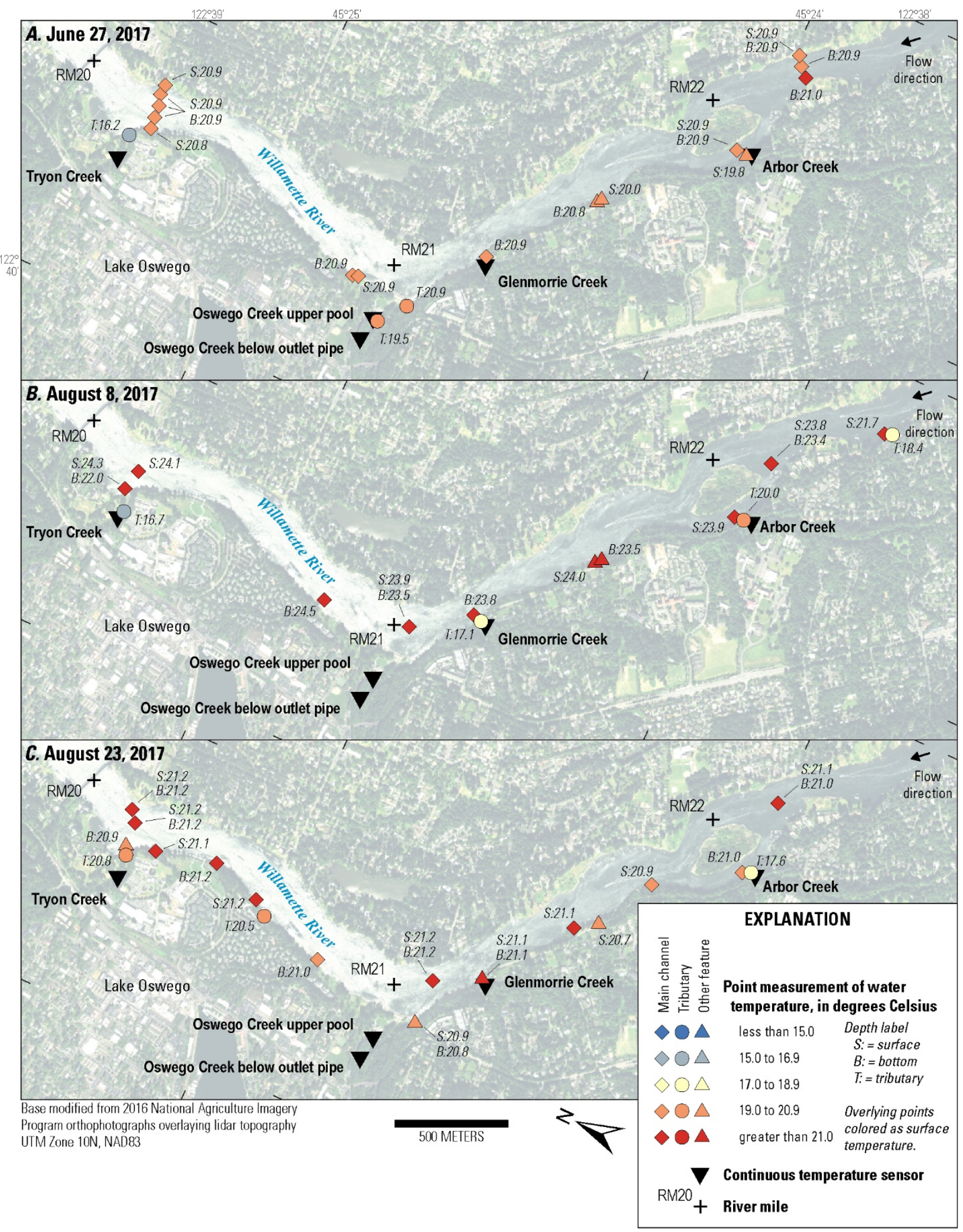

Figure 8. Maps showing water temperature point measurements for June 27, 2017 (A), August 1, $2017(B)$, and August 23, $2017(C)$, in the Lake Oswego Reach, northwestern Oregon. 


\section{Wilsonville Reach}

Water temperature measurements in the Wilsonville Reach were collected in summer 2017. Data collection focused on the approximately 5-km long reach of the river adjacent to the City of Wilsonville limits (fig. 1). Water temperature readings from continuous temperature sensors are plotted in figure 9. Locations and water temperature values of point measurements are shown for June 28, and August 2 and 23, 2017, in figure 10.

Tributaries with continuous water temperature sensors in the Wilsonville Reach were consistently $1-10^{\circ} \mathrm{C}$ cooler than the main channel of the Willamette River at Newberg (USGS streamgage 14197900) during summer except for short periods when Coffee Lake Creek was warmer than the river (fig. 9). Summer water temperatures ranged from a relatively consistent $13{ }^{\circ} \mathrm{C}$ in the unnamed tributary at RM 38.7 to nearly $23{ }^{\circ} \mathrm{C}$ for short periods in Coffee Lake Creek. Tributaries typically had diel fluctuations ranging from 3 to $5{ }^{\circ} \mathrm{C}$. Seasonal fluctuations in tributary temperatures, when present, likely were owing to expected fluctuations in their heat budgets caused by weather patterns and the changing seasons; see, for example, the patterns in water and air temperatures during the warmer period of July 22-August 14, 2017 (figs. 2 and 9).

The water temperature of the Willamette River main channel varied slightly throughout the Wilsonville Reach, but was always greater than $20^{\circ} \mathrm{C}$ during summer sampling trips (fig. 10). Surface temperature measurements on a single day ranged from 1 to $2{ }^{\circ} \mathrm{C}$. In some locations, such as near Corral Creek on August 2, 2017 (fig. 10B), a $1.1{ }^{\circ} \mathrm{C}$ difference in water temperature was measured between the surface and bottom of the water column. Several other main-channel measurements near tributary junctions showed differences of $0.3-0.5{ }^{\circ} \mathrm{C}$ between the surface and bottom of the water column, which may be attributed either to the plunging of cooler water inputs from nearby tributaries or from a small amount of thermal stratification caused by the normal daily cycle of surface heating. Additional field data collection would be necessary to evaluate the factors contributing to these thermal differences. In some areas, measured water temperatures were relatively constant. For example, a cross section near RM 37 on June 28, 2017 showed that water temperature at 9 m of depth was within $0.1{ }^{\circ} \mathrm{C}$ of surface water temperature and consistent across the transect. Thermal stratification, it seems, is not always strong and measurable in this reach of the river, and well-mixed conditions at depth are not uncommon.

The simple planform of the Willamette River through the Wilsonville Reach, which is pooled behind Willamette Falls farther downstream, limits the number of off-channel features in this reach. Therefore, most point water temperature measurements focused on tributary mouths and seeps along the riverbanks. Few additional tributaries exist in this reach besides those with continuous water temperature sensors except near RM 39, where small tributaries on either side of the river were cooler than the main channel when point measurements were taken (fig. 10). Point measurements also showed some areas of slightly cooler and slightly warmer water, relative to the main channel, seeping out of the southern bank near RM 37.5. The time of day when point-temperature measurements were taken likely has an influence on measured water temperature values and ranges, which was not systematically accounted for in this report. 


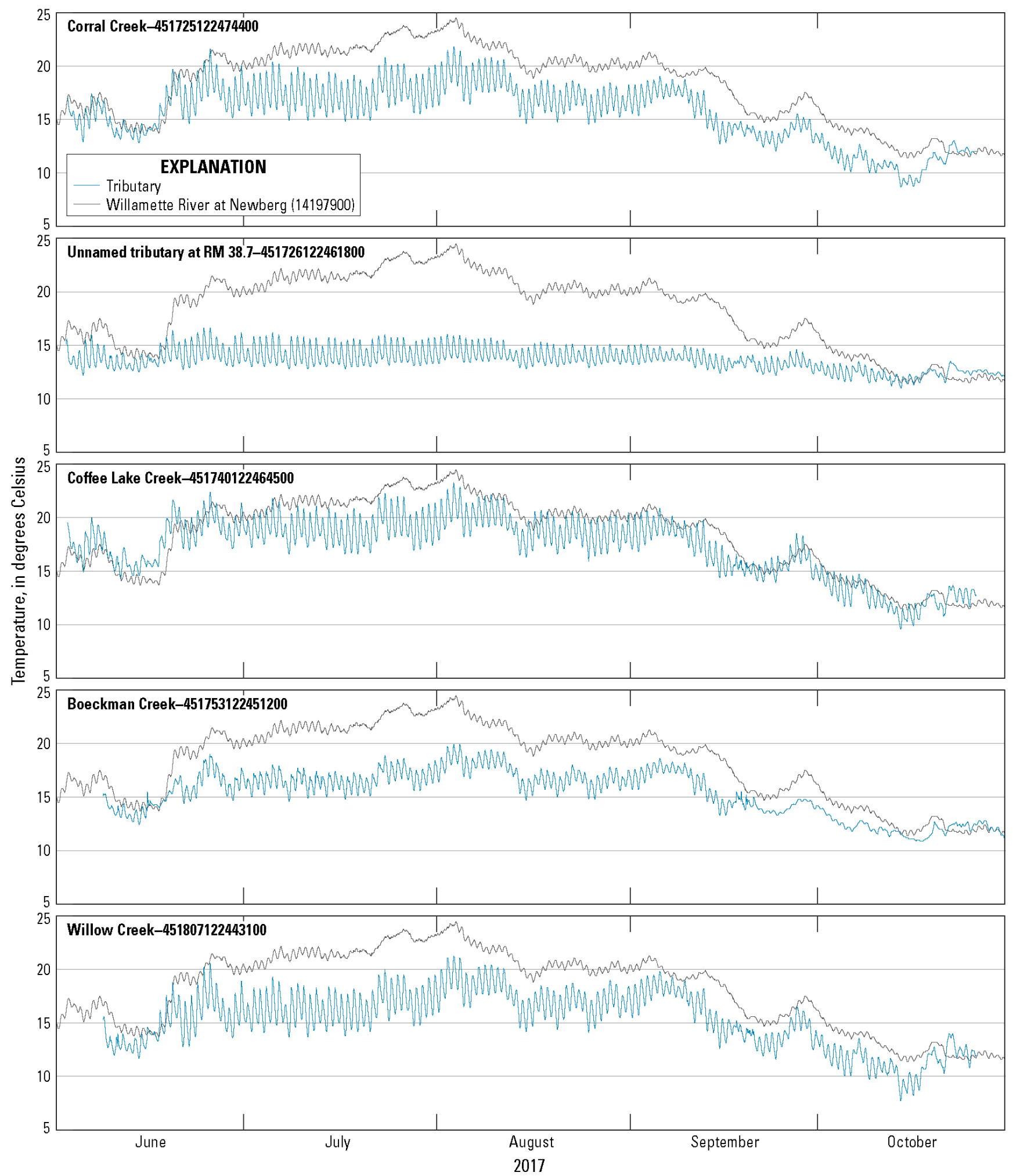

Figure 9. Graphs showing water temperature of tributaries in the Wilsonville Reach and in the Willamette River at Newberg (USGS streamgage 14197900), northwestern Oregon, summer 2017. 


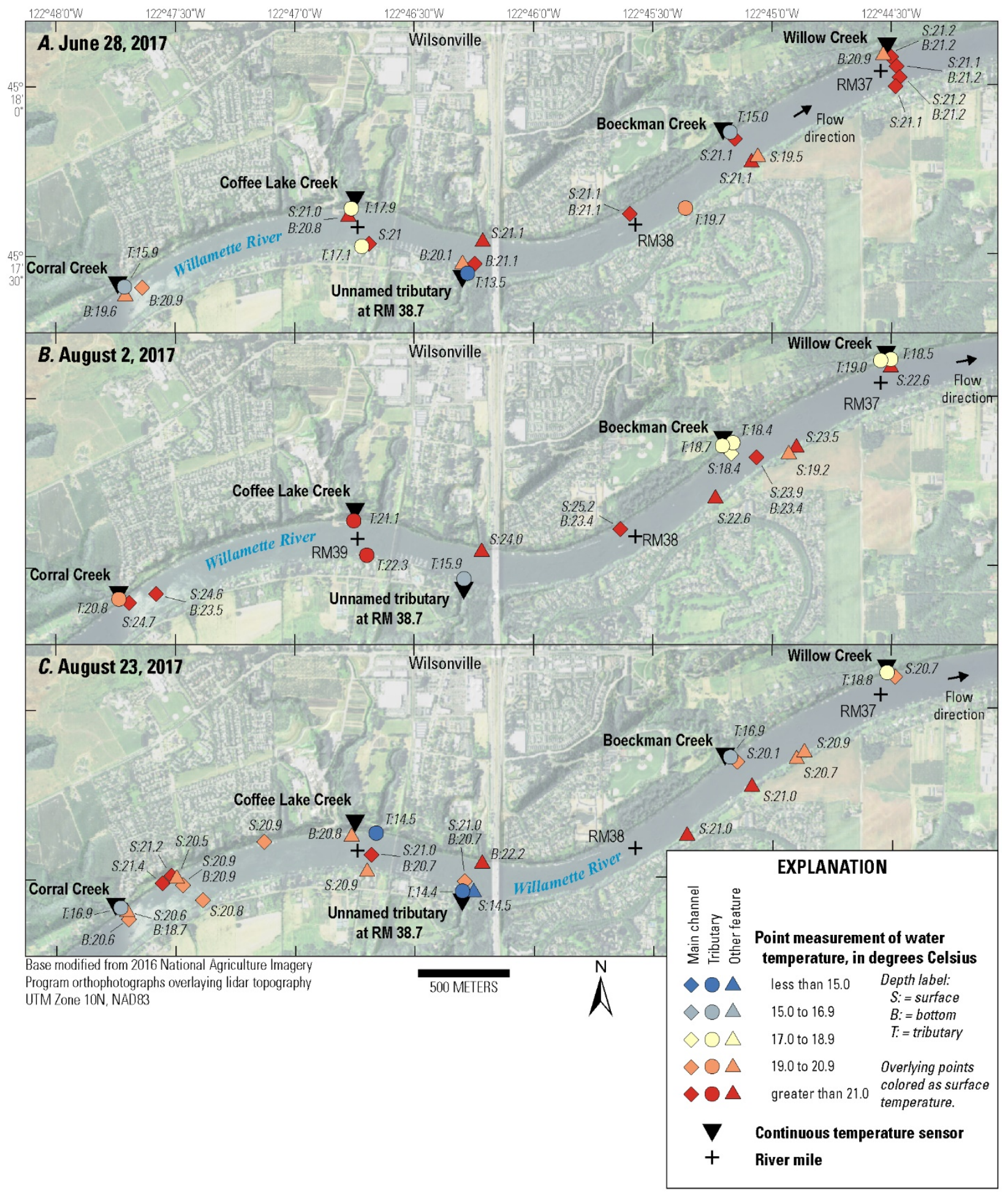

Figure 10. Maps showing water temperature point measurements for June 28, 2017 (A), August 2, $2017(B)$, and August 23, 2017 (C), in the Wilsonville Reach, northwestern Oregon. 


\section{Major Tributary Reaches}

Three major tributaries to the Willamette River, the Clackamas and Molalla Rivers, and Johnson Creek, were included in this study to identify potential areas of cool water in the lowermost 1.5-2.5 km of each tributary near their junction with the Willamette River. Of these three major tributaries, continuous temperature sensors were placed only in Johnson Creek as part of monitoring in the Lake Oswego Reach in summer 2016. Additional continuous temperature measurements for each tributary are available at long-term USGS streamgages (see section, "Ongoing Temperature Data at Long-Term U.S. Geological Survey Sites”). Water temperature point measurements along the Clackamas and Molalla Rivers and Johnson Creek were made in summer 2017. Locations and temperature values of point measurements are shown in figure $11 \mathrm{~A}$ for Johnson Creek on July 31 , 2017; figure $11 B$ for the Clackamas River on August 1, 2017; and figure $11 C$ for the Molalla River on August 2, 2017.

Water temperature in Johnson Creek cooled slightly along this $1.5-\mathrm{km}$ monitoring reach as it neared its confluence with the Willamette River, with temperatures ranging from 19.6 to $17.6{ }^{\circ} \mathrm{C}$ (fig. $11 \mathrm{~A}$ ). The mouth of Johnson Creek was nearly $1{ }^{\circ} \mathrm{C}$ cooler than the upstream part of this reach, perhaps owing in part to a greater amount of local riparian shade (appendix 1). Although this reach of Johnson Creek lacks off-channel features, smaller tributaries (some of which flow through pipes and culverts) contributed both cooler and warmer water (fig. 11A).

The Clackamas River warmed slightly in the downstream direction along its lowermost $2.5-\mathrm{km}$ reach approaching the confluence with the Willamette River, with water temperatures ranging from 18.8 to $20.4{ }^{\circ} \mathrm{C}$ (fig. $11 B$ ), whereas water temperatures at the nearby long-term site on the Clackamas River near Oregon City (USGS streamgage 14211010) ranged from 18.5 to $22.4{ }^{\circ} \mathrm{C}$ on the same day. Despite that slight warming at the long-term site, measurements along the lower Clackamas River typically were still more than $4{ }^{\circ} \mathrm{C}$ cooler than measurements on the Willamette River on the day of the monitoring trip (fig. $11 B$ ). This reach of the Clackamas River lacks many tributary junctions and offchannel features (besides the large, notable gravel pit on the southern side of the river), but its cooler water is ideal for attracting cold-water fish species of the Willamette River in times of thermal stress.

The lower $1.5-\mathrm{km}$ of the Molalla River main channel ranged in water temperature from 22.3 to $24.2{ }^{\circ} \mathrm{C}$ with no clear longitudinal trend in the measured temperatures (fig. $11 \mathrm{C}$ ). Although the morphology of the lower Molalla River suggests more recent geomorphic changes than other Willamette River tributaries, there were few off-channel areas connected to the main channel that might provide cold-water refuges (such as alcoves) within the monitoring reach on the date the measurements were taken. One alcove measured in this reach was substantially cooler $\left(\right.$ at $\left.15.6{ }^{\circ} \mathrm{C}\right)$ than the main channel. Slightly upstream of that cool alcove, another small alcove was warmer than the main channel (at $26.7^{\circ} \mathrm{C}$ ).

For all tributary reaches, the time of day when point-temperature measurements were taken likely has an influence on measured water temperature values and ranges, which was not systematically accounted for in this report. 

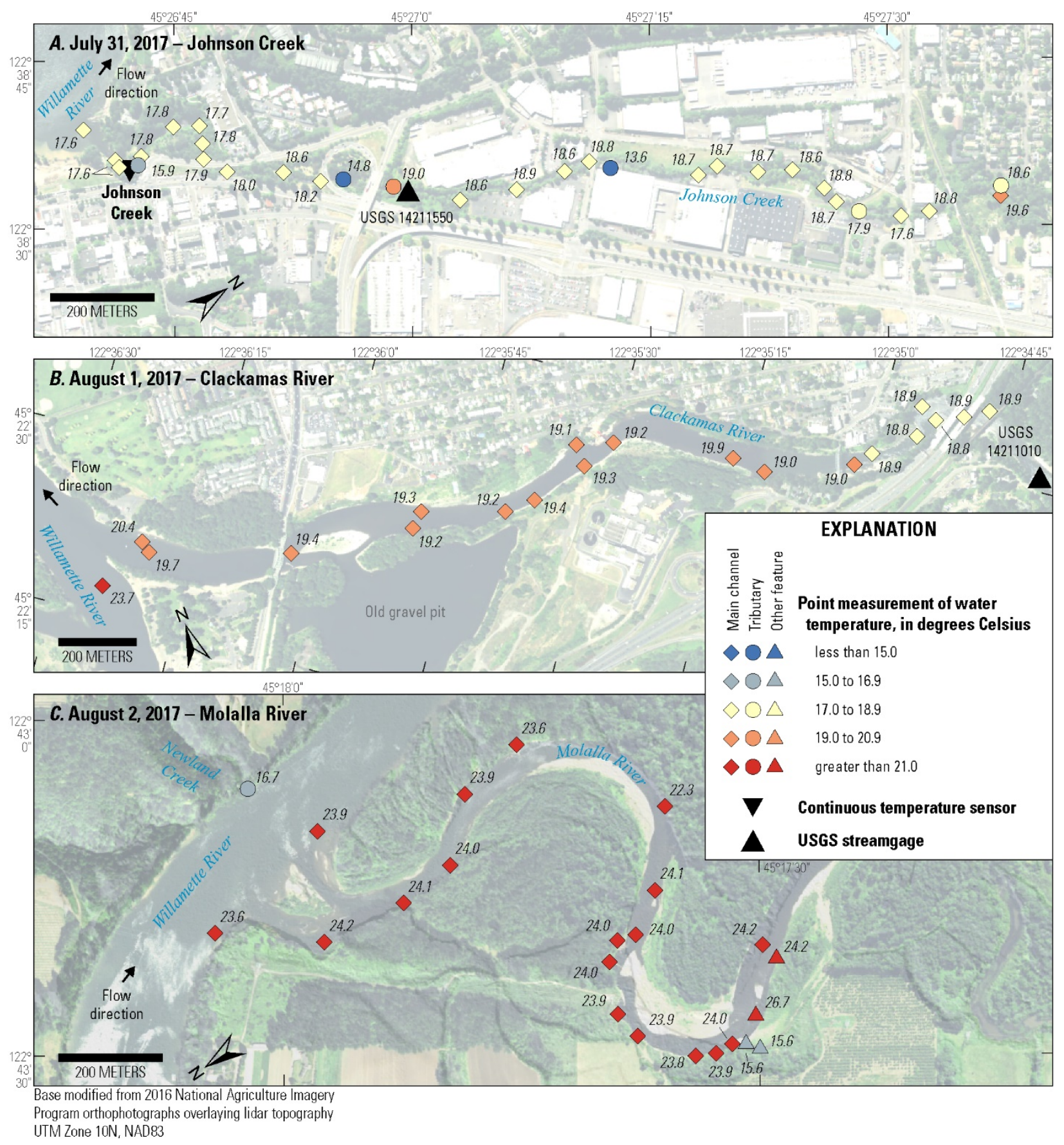

Figure 11. Maps showing water temperature point measurements for the lower 2 kilometers $(\mathrm{km})$ of Johnson Creek on July $31(A)$, the lower $2.5 \mathrm{~km}$ of the Clackamas River on August $1(B)$, and the lower $1.5 \mathrm{~km}$ of the Molalla River on August 2 (C), northwestern Oregon, 2017. For this figure, the term "Main channel" includes the main channel of these major tributaries themselves; in some cases, smaller streams entering these rivers also were measured and are labeled as "tributary" locations on the map. 


\section{Summary}

In many locations, the lower Willamette River in northwestern Oregon has a confining bedrock channel and lacks the alluvial channel morphology and associated geomorphic processes that create off-channel features such as alcoves and side channels that are likely to support cold-water refuges. These features are more numerous in the gravel-bed reaches of the Willamette River upstream of Newberg and in gravel-bed reaches of tributaries that are less altered by development. Therefore, tributary mouths are the channel features where cooler water is most commonly found along the lower Willamette River when the main channel is warm during summer. For example, Tryon and Boeckman Creeks typically are more than $5{ }^{\circ} \mathrm{C}$ cooler than the Willamette River during summer. Other tributaries, such as Balch and Oswego Creeks, are warmer than the Willamette River during a large part of the summer. Cold-water plumes of undetermined sizes are detectable at the bottom of the main channel of the Willamette River near the mouths of some tributaries. Tributaries vary greatly in terms of drainage area and contributing flow, however, and some are small. Water temperature measurements from this study showed that the main channel of the Willamette River tends to be well mixed throughout its cross section and with depth at most locations, although differences between top and bottom water temperatures were measured at some locations in the City of Wilsonville monitoring reach. Additionally, water temperature measurements in the Willamette River near known fault lines in the City of Lake Oswego monitoring reach did not detect any substantive sites with cold water. This data-collection study addressed some important data gaps and has helped to characterize the thermal characteristics of the lower Willamette River and many of its tributaries. Data and information from this study provide important context for identifying potential cold-water refuge areas in the lower Willamette River reach, and for prioritizing management and conservation actions to protect or enhance these features.

\section{Acknowledgments}

Field assistance for this study was provided by U.S. Geological Survey (USGS) personnel Cassandra Smith and Gabe Gordon. The authors appreciate the assistance and insights of Sonja Johnson and Rob Amsberry (City of Lake Oswego); Anne MacDonald (formerly with City of Lake Oswego); Kerry Rappold and Sarah Sand (City of Wilsonville); and Rose Wallick (USGS) in helping to plan and carry out this study. 


\section{References Cited}

City of Portland, 2014, TMDL implementation plan for the Willamette River and tributaries: City of Portland, Oregon, 31 p., https://www.portlandoregon.gov/bes/article/509613.

Dugdale, S.J., Bergeron, N.E., and St-Hilaire, A., 2013, Temporal variability of thermal refuges and water temperature patterns in an Atlantic salmon river: Remote Sensing of the Environment, v. 139, p. 358-373, at https://doi.org/10.1016/j.rse.2013.05.018.

Hines, W.G., McKenzie, S.W., Rickert, D.A., and Rinella, F.A., 1977, Dissolved-oxygen regimen of the Willamette River, Oregon, under conditions of basinwide secondary treatment: U.S. Geological Survey Circular 715-I, 152 p., at https://pubs.usgs.gov/circ/1977/0715i/report.pdf.

Ma, L., Madin, I.P., Olson, K.V., and Watzig, R.J., 2009, Oregon geologic data compilation, release 5: Oregon Department of Geologic and Mineral Industries digital database.

Mangano, J.F., Buccola, N.L., Piatt, D.R., Smith, C.D., and White, J.S., 2017, Point measurements of temperature and water quality in main-channel and off-channel features of the Willamette River, 2015-16: U.S. Geological Survey data release, https://doi.org/10.5066/F7VQ315D.

Oregon Department of Environmental Quality, 2016b, Water quality standards - Beneficial uses, policies, and criteria for Oregon-Definitions: Oregon Administrative Rule 340-041-0002(10), Oregon Department of Environmental Quality, accessed August 2, 2018, at https://secure.sos.state.or.us/oard/displayDivisionRules.action?selectedDivision=1458.

Oregon Department of Environmental Quality, 2016a, Water quality standards - Beneficial uses, policies, and criteria for Oregon-Water temperature: Oregon Administrative Rule 340-0410028(4)(d), Oregon Department of Environmental Quality, accessed August 2, 2018, at https://secure.sos.state.or.us/oard/viewSingleRule.action?ruleVrsnRsn=244176.

Oregon State University, 2018, Willamette fish database: Corvallis, Oregon State University Department of Fisheries and Wildlife database, accessed September 24, 2018, at http://gis.nacse.org/wrfish/index.php.

National Marine Fisheries Service, 2008, Willamette Basin biological opinion—Endangered Species Act section 7(a)(2) consultation: National Oceanic and Atmospheric Administration Fisheries Log Number F/NWR/2000/02117 [variously paged], accessed September 20, 2018, at https://www.westcoast.fisheries.noaa.gov/fish_passage/willamette_opinion/.

Piatt, D.R., Smith, C.D., Gordon, G.W., and Mangano, J.F., 2018, Point measurements of temperature and water quality in the main channel and off-channel features of the lower reaches of the Willamette River, Clackamas River, Molalla River, and Johnson Creek, 2017: U.S. Geological Survey data release, https://doi.org/10.5066/F7KH0MJP.

Torgersen, C.E., Ebersole, J.L., and Keenan, D.M., 2012, Primer for identifying cold-water refuges to protect and restore thermal diversity in riverine landscapes: U.S. Environmental Protection Agency, Report no. EPA 910-C-12-001, at https://nepis.epa.gov/Exe/ZyPURL.cgi?Dockey=P100E45N.TXT. 
U.S. Geological Survey, 2018a, The StreamStats program: U.S. Geological Survey web page, https://water.usgs.gov/osw/streamstats/.

U.S. Geological Survey, 2018b, USGS water data for the nation: U.S. Geological Survey National Water Information System, accessed September 20, 2018, at http://dx.doi.org/10.5066/F7P55KJN.

U.S. Geological Survey, 2018c, USGS water services: U.S. Geological Survey web page, https://waterservices.usgs.gov/.

U.S. Geological Survey, 2018d, Welcome to USGS-R: U.S. Geological Survey web page, https://owi.usgs.gov/R/.

U.S. Geological Survey, 2018e, USGS data grapher and data tabler: U.S. Geological Survey Oregon water Science Center web page, https://or.water.usgs.gov/grapher/.

Vile, J.S., and Friesen, T.A., 2004, Description and categorization of nearshore habitat in the lower Willamette River, in Friesen, T.A., ed., Biology, behavior, and resources of resident and anadromous fish in the lower Willamette River-Final report of research, 2000-2004: Oregon Department of Fish and Wildlife, p. 17-62, online at https://www.portlandoregon.gov/bes/article/79249.

Wagner, R.J., Boulger, R.W., Jr., Oblinger, C.J., and Smith, B.A., 2006, Guidelines and standard procedures for continuous water-quality monitors - Station operation, record computation, and data reporting: U.S. Geological Survey Techniques and Methods, book 1, chap. D3, accessed September 10, 2018, at http://pubs.water.usgs.gov/tm1d3. 


\section{Appendix 1. Photographs of Tributaries with Continuous Temperature Sensors}

Each photograph is accompanied with some basic information and details of each site. These photographs are for visual reference only and should not be used for analyses. All photographs are by the U.S. Geological Survey and were taken in Oregon.

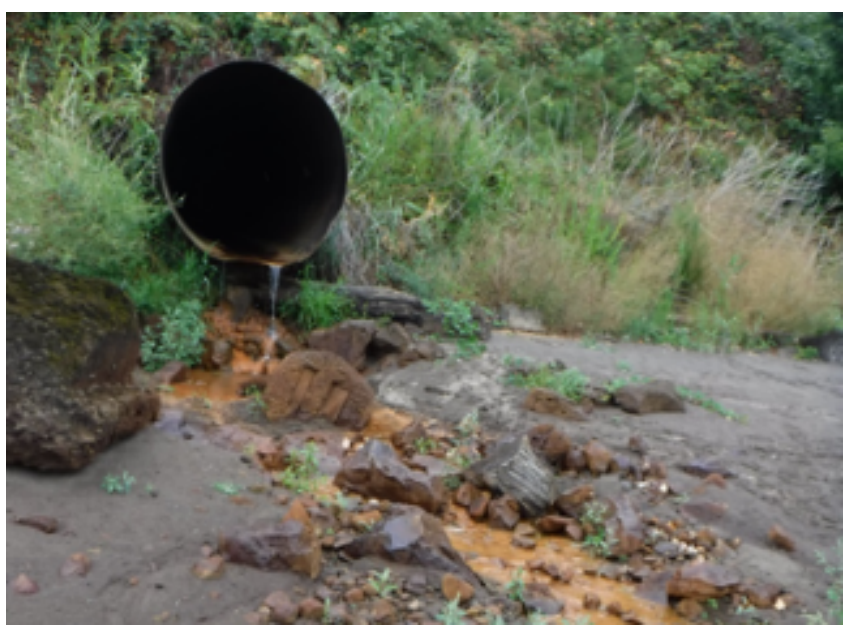

Site name: Unnamed tributary at river mile 4.9

Willamette River, river mile: 4.9

NWIS site No.: 453548122465100

Photograph date: August 31, 2016

Other notes: Believed to be the confluence of Linnton Creek with the Willamette River.

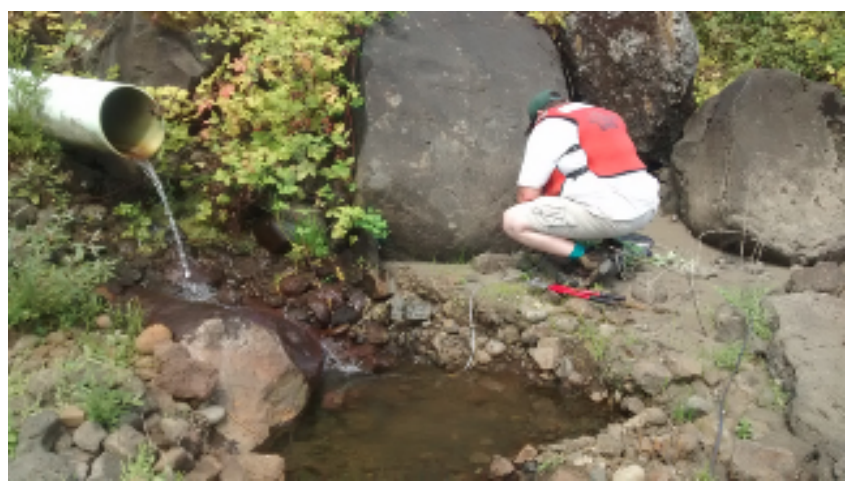

Site name: Unnamed tributary at river mile $\mathbf{5 . 9}$

Willamette River, river mile: 5.9

NWIS site No.: 453509122460800

Photograph date: July 21, 2016

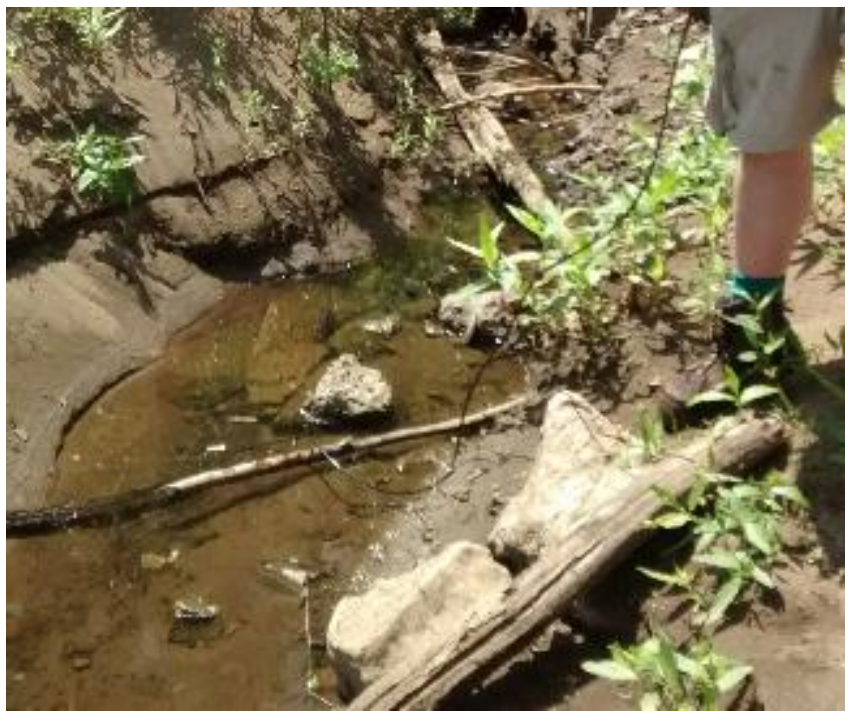

Site name: Doane Creek at mouth, at Portland Willamette River, river mile: 6.9

NWIS site No.: 453432122445800

Photograph date: July 21, 2016

Other notes: Stream flows out of a culvert. 


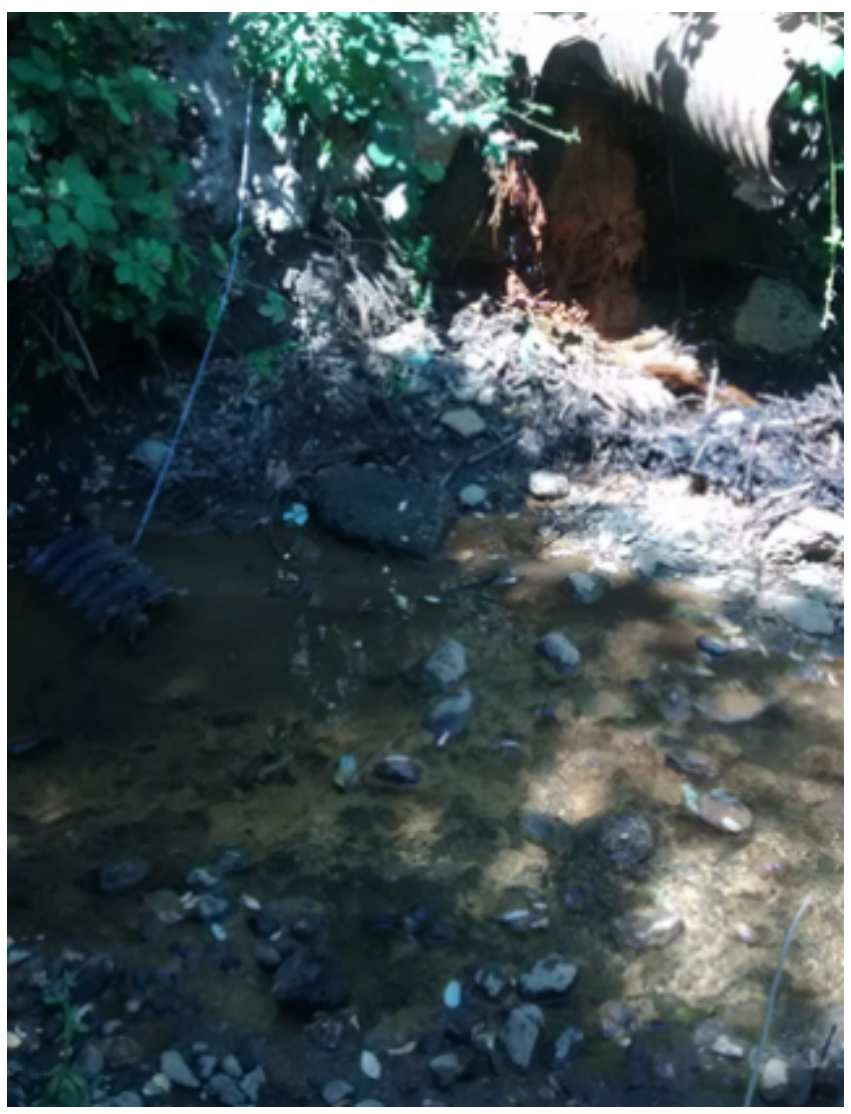

Site name: Saltzman Creek at mouth, at Portland

Willamette River, river mile: 7.8

NWIS site No.: 453405122442800

Photograph date: July 21, 2016

Other notes: Stream flows out of a culvert.

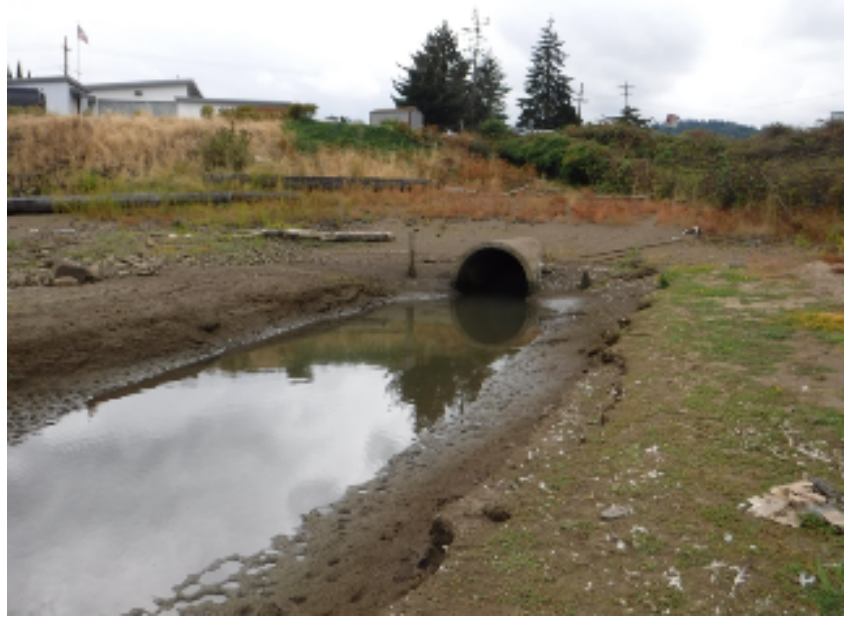

Site name: Balch Creek at mouth, at Portland

Willamette River, river mile: 9.8

NWIS site No.: 453258122422100

Photograph date: August 31, 2016

Other notes: Tidal influence during autumn; backwatered in photograph. Sensor was placed in culvert to only collect streamflow during times of low stage in the Willamette River. 


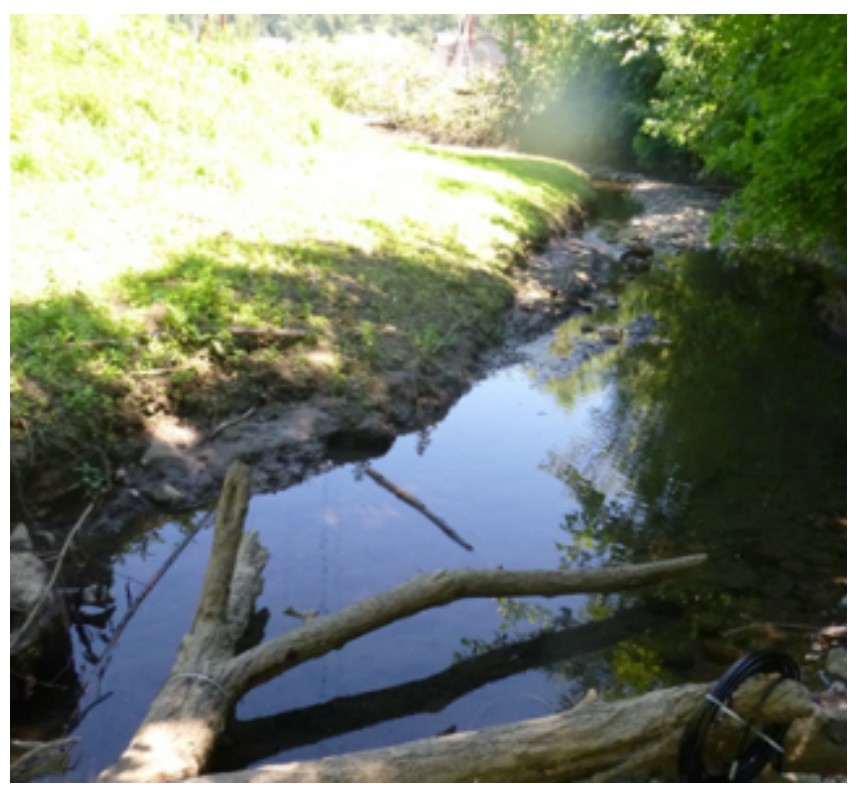

Site name: Stephens Creek at mouth, at Portland

Willamette River, river mile: 16.2

NWIS site No.: 452808122401100

Photograph date: July 14, 2016

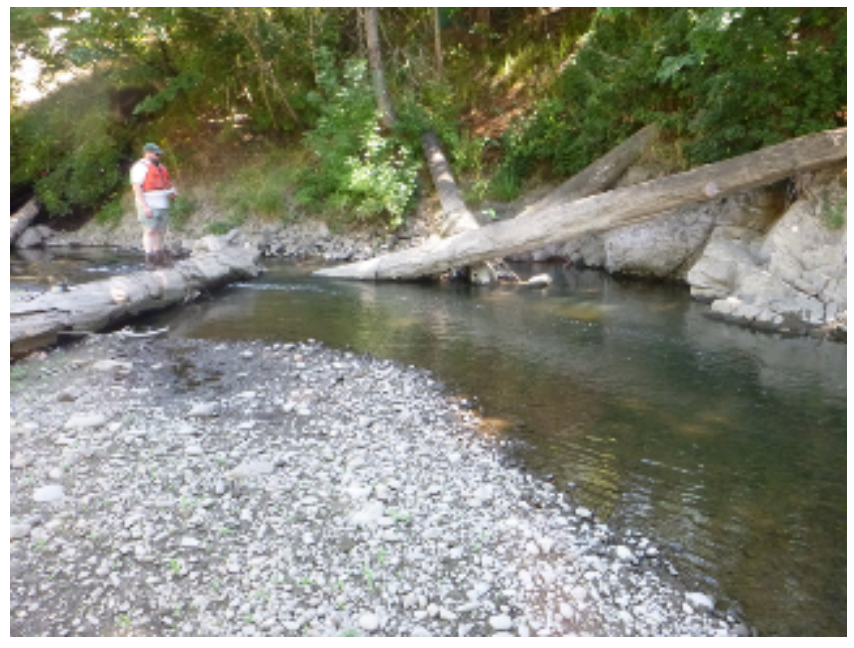

Site name: Johnson Creek near mouth, at Milwaukie Willamette River, river mile: 18.4

NWIS site No.: 452642122383600

Photograph date: July 14, 2016

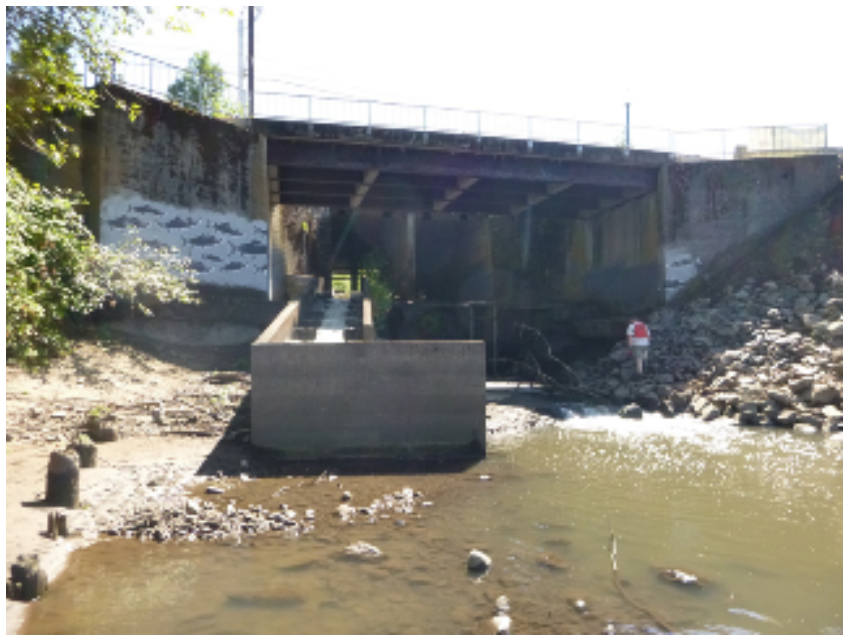

Site name: Kellogg Creek at mouth, below Kellogg Dam Willamette River, river mile: 18.5

NWIS site No.: 452630122383200

Photograph date: July 14, 2016

Other notes: Flow is directly out of small dam. 

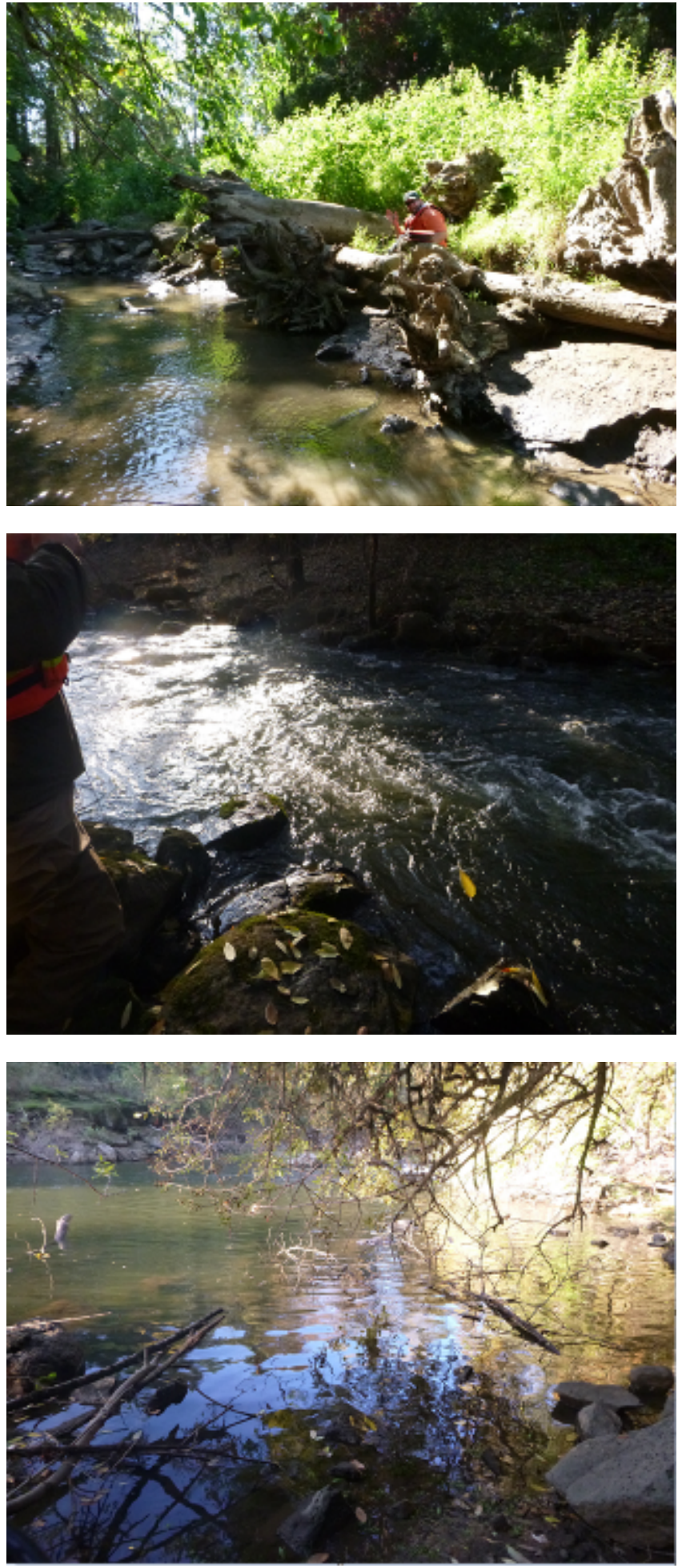

Site name: Tryon Creek near mouth, at Lake Oswego

Willamette River, river mile: 20.1

NWIS site No.: 452521122392900

Photograph date: July 13, 2016

Site name: Oswego Creek near dam outlet

Willamette River, river mile: 21.0

NWIS site No.: 452439122394600

Photograph date: October 26, 2017

Other notes: Sensor placed in flowing water downstream of Oswego Dam.

\section{Site name: Oswego Creek in large pool}

Willamette River, river mile: 21.0

NWIS site No.: 452439122394200

Photograph date: October 26, 2017

Other notes: Sensor placed in large pool, which is mostly the backwater of the main-channel Willamette River but appears to have some influence by inputs from Oswego Creek below Oswego Dam. 

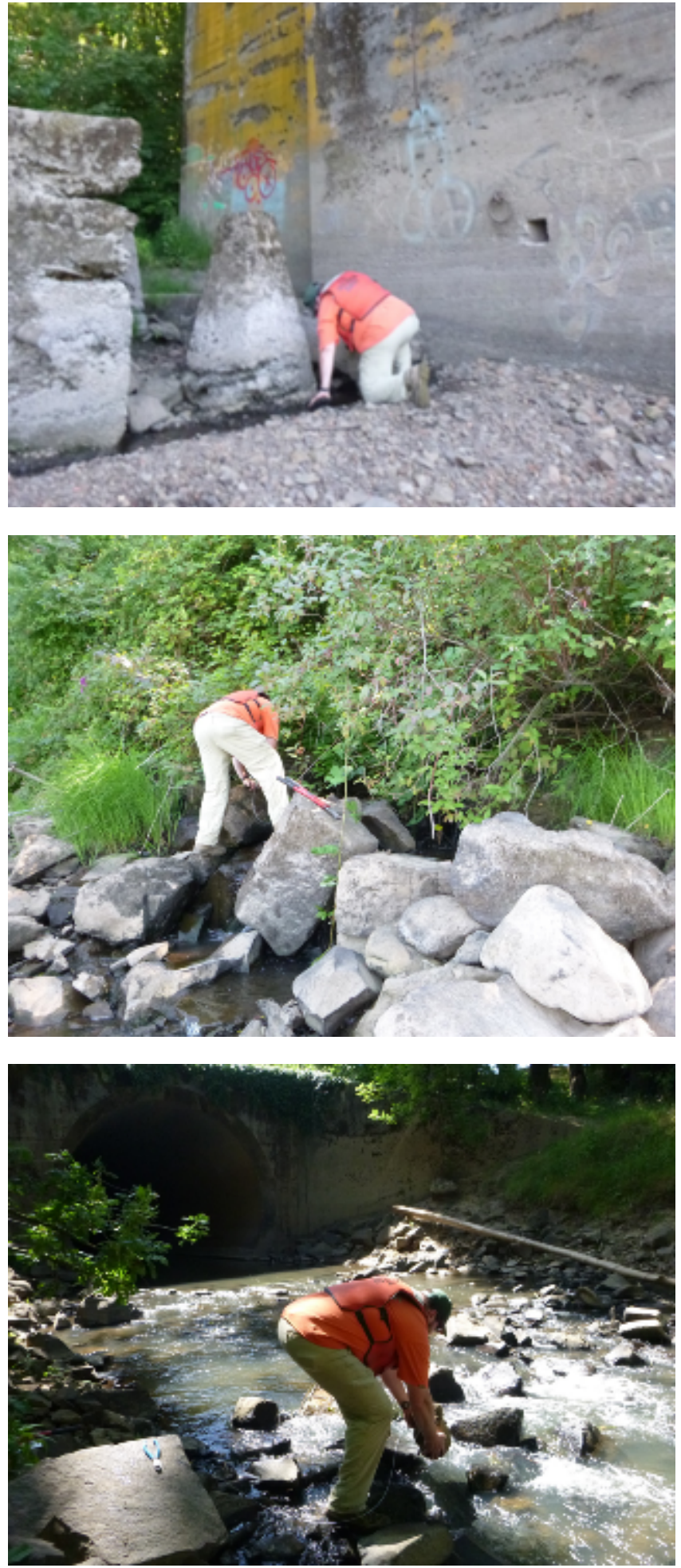

Site name: Glenmorrie Creek at mouth, at Lake Oswego

Willamette River, river mile: 21.3

NWIS site No.: 452428122392000

Photograph date: July 13, 2016

Other notes: Water is dark line along concrete pillars; flow was not abundant but was continuous throughout the summer.

Site name: Arbor Creek at mouth, at Lake Oswego

Willamette River, river mile: 22.0

NWIS site No.: 452360122383800

Photograph date: July 13, 2016

Other notes: Stream breaks into several distributaries through large debris fan.

Site name: Abernathy Creek near mouth, at Oregon City Willamette River, river mile: 25.5

NWIS site No.: 452153122360500

Photograph date: July 13, 2016 


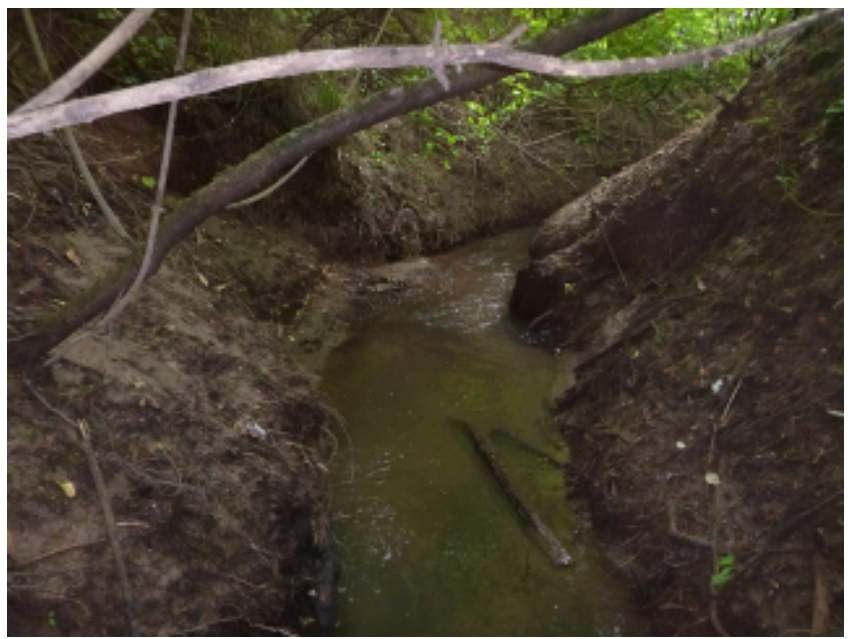

Site name: Willow Creek near mouth, at Wilsonville

Willamette River, river mile: 36.9

NWIS site No.: 451807122443100

Photograph date: June 8, 2017

Other notes: The City of Wilsonville refers to this creek as

Meridian Creek.

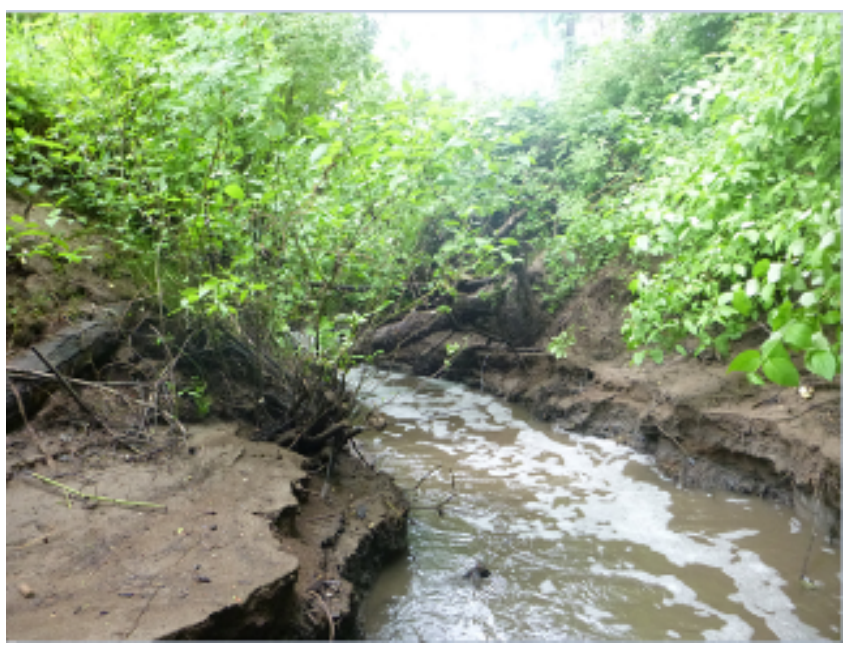

Site name: Boeckman Creek near mouth, at Wilsonville Willamette River, river mile: 37.6

NWIS site No.: 451753122451200

Photograph date: June 8, 2017

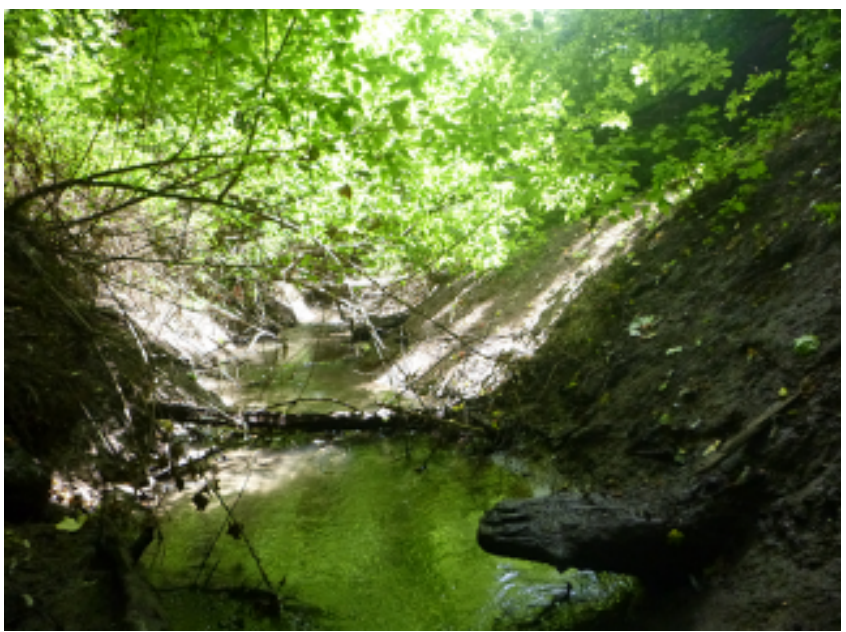

Site name: Unnamed creek near mouth, at RM 38.7 near Wilsonville

Willamette River, river mile: 38.7

NWIS site No.: 451726122461800

Photograph date: June 2, 2017 


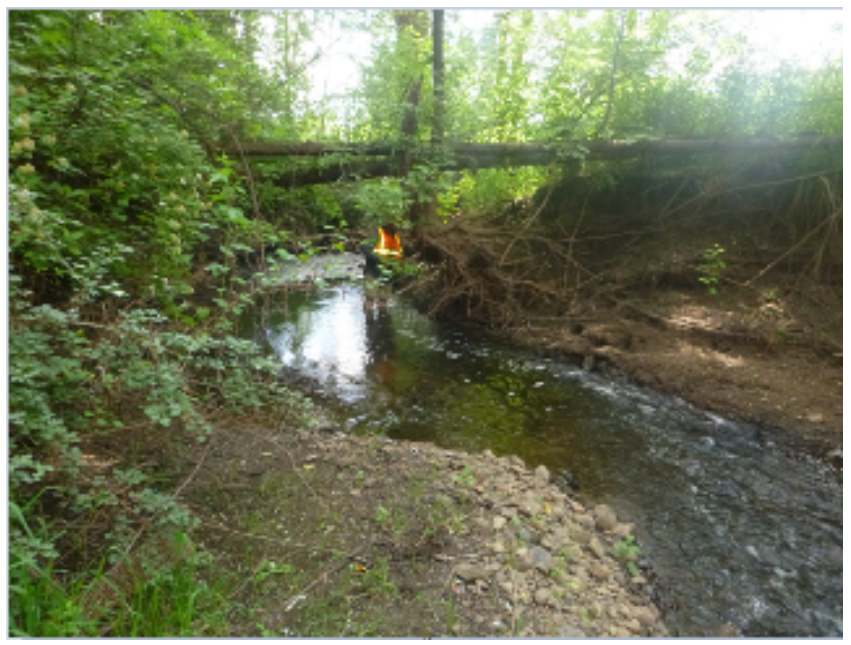

Site name: Coffee Lake Creek near mouth, at Wilsonville

Willamette River, river mile: 39.0

NWIS site No.: 451740122464500

Photograph date: June 2, 2017

Other notes: Specific conductance was noticeably elevated in this creek.

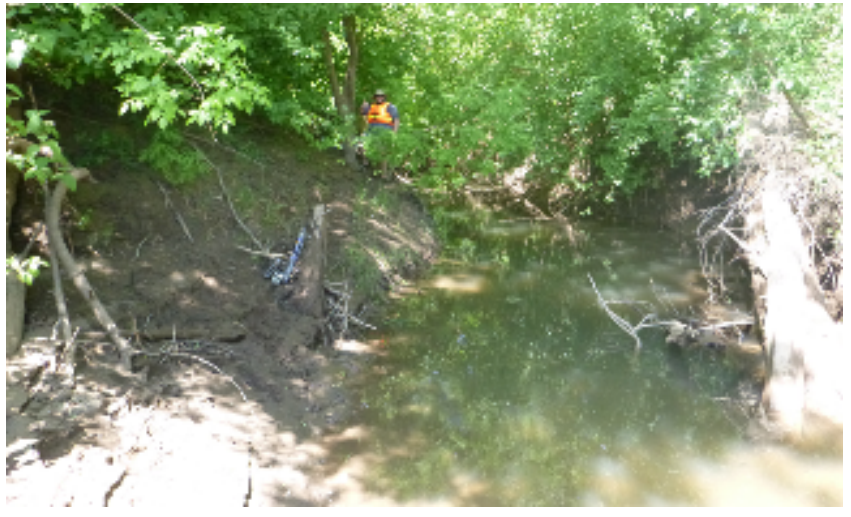

Site name: Corral Creek near mouth, at Wilsonville Willamette River, river mile: 39.9

NWIS site No.: 451725122474400

Photograph date: June 2, 2017 

Publishing support provided by the U.S. Geological Survey Science Publishing Network, Tacoma Publishing Service Center

For more information concerning the research in this report, contact the Director, Oregon Water Science Center

U.S. Geological Survey

2130 SW 5th Avenue

Portland, Oregon 97201

https://or.water.usgs.gov 
